\title{
Plant communities with Carex frigida in the Julian Alps (northwestern Slovenia)
}

\author{
Igor Dakskobler ${ }^{1} \&$ Andrej Martinčič ${ }^{2}$
}

Key words: phytosociology, synsystematics, Cystopteridion, Adenostylion alliariae, Cratoneurion, Triglav National Park, Natura 2000, Slovenia.

Ključne besede: fitocenologija, sinsistematika, Cystopteridion, Adenostylion alliariae, Cratoneurion, Triglavski narodni park, Natura 2000, Slovenija.

\begin{abstract}
In already known localities in the Julian Alps (Mangart, Malo Polje, Zeleno Jezero, Blehe under Šoštar) and in several new ones (Loška Koritnica, Bavh, Spodnji Lepoč, Mlinarica, Konjska planina, Mali Babanski Skedenj) we inventoried the stands along the subalpine-alpine springs and spring areas where Carex frigida frequently occurs as the predominant vascular plant. We classified them into the following associations: Saxifrago aizoidis-Caricetum ferrugineae, Caricetum davallianae s. lat., Ranunculo traunfellneri-Paederotetum luteae, Carici frigidae-Petasitetum albi (alliance Adenostylion alliariae) and Palustriello decipientisCaricetum frigidae (alliance Cratoneurion). The latter two were described as new. Based on comparisons with similar communities along mountain springs we discussed the most appropriate classification of the latter into higher syntaxonomic units.

\section{Izvleček}

V Julijskih Alpah smo na že znanih (Mangart, Malo polje, Zeleno jezero, Blehe pod Šoštarjem) in tudi nekaterih novih nahajališčih (Loška Koritnica, Bavh, Spodnji Lepoč, Mlinarica, Konjska planina, Mali Babanski Skedenj) popisali sestoje ob subalpinsko-alpinskih izvirih in povirjih, v katerih med cevnicami pogosto prevladuje vrsta Carex frigida. Uvrstili smo jih v naslednje asociacije: Saxifrago aizoidis-Caricetum ferrugineae, Caricetum davallianae s. lat., Ranunculo traunfellneri-Paederotetum luteae, Carici frigidae-Petasitetum albi (zveza Adenostylion alliariae) in Palustriello decipientis-Caricetum frigidae (zveza Cratoneurion). Slednji dve asociaciji smo opisali kot novi in pri drugi na podlagi primerjav s podobnimi združbami ob gorskih izvirih razpravljali o najbolj ustrezni uvrstitvi v višje sintaksonomske enote.
\end{abstract}




\section{Introduction}

Carex frigida (ice sedge) is a south-European montane species distributed across most of the Alps, a character species of the order Caricetalia davallianae (Aeschimann et al. 2004b: 826). In the Slovenian Red List it is classified as rare (R) (Anon. 2002). It thrives on wet sites along streams and springs in the alpine belt (Martinčič 2007: 820). The list of ice sedge localities was published by T. Wraber \& Skoberne (1989: 89-90), who made the map of its distribution area that was referred to also by Jogan et al. (2001: 86). Its localities and sites were discussed the most extensively by T. Wraber (1967: 61, 1969: 82, 1983: 121), who mainly reported those under Mangart: Gladki Rob, Rdeča Skala, Rdeča Glava, under Rateški Mali Mangart (to the NW above Prodi), Na Jami, on Malo Polje at Velo Polje, and along the lake of Zeleno Jezero in the Triglav Lakes Valley. At the beginning of fieldwork with his students on Komna on 4 July 1979 Wraber found its lowest locality on "rocks wet with the sprinkling of the Savica spring at the elevation of $900 \mathrm{~m}$ " (this information was published in T. Wraber \& Skoberne, ibid., but the description of the find and the locality was recorded in his field notes, which are kept at Wraber's library in the Ljubljana Botanical Garden). The southernmost known locality of this sedge in Slovenia, Blehe under Šoštar at Mt. Črna Prst, was published and described with a phytosociological table, but without mosses (Dakskobler 2003: 46, 62-63). In the Italian part of the Julian Alps it was reported for the locality under Viš/Jof Fuart (Marchesetti 1879 , as reported by T. Wraber 1967: 61). This locality is recorded also in the distribution map for Friuli Venezia Giulia (Poldini 2002: 110). Other localities in Friuli are more to the west, in the Carnic Alps. Similarly, ice sedge localities in Carinthia, Austria, are situated to the west and north of the Julian Alps and the Karawanks (Hartl et al. 1992: 120). T. Wraber (1967, ibid.) found the ice sedge under Viš / Jof Fuart on 21.9.1966 at a well on spring soil on the southeastern slopes of this mountain directly behind the Corsi hut at the elevation of $1870 \mathrm{~m}$, accompanied by Deschampsia cespitosa, Saxifraga stellaris subsp. alpigena, Arabis pumila, Ranunculus traunfellneri, Achillea atrata, Soldanella minima, Salix alpina, Tussilago farfara, Campanula cochleariifolia and Cerastium austroalpinum, among others. We also recorded ice sedge under Mt. Viš: in the gravelly spring area (source) under the Corsi hut, at the elevation of $1750 \mathrm{~m}$, together with Heliosperma pusillum and Valeriana saxatilis, but did not make a detailed inventory (Det. I. \& V. Dakskobler, 22. 7. 2013). This clearly suggests that there are more localities under Viš / Jof Fuart.
Our findings corroborate T. Wraber's observation (1983: 121) that "the floristic composition of stands with Carex frigida is very heterogeneous".

After 2003 we visited and confirmed some of the previously known localities of ice sedge under Mangart (Prodi, $\mathrm{Na}$ Jami), on Malo Polje and at Zeleno Jezero, and found several new localities in the Julian Alps. We made phytosociological relevés for most of them. We collected the mosses and identified them, which enabled us to process and classify the recorded communities using a syntaxonomic system.

\section{Methods}

Our analysis was based on the relevés recorded on the sites of Carex frigida using the Central-European (BraunBlanquet 1964) phytosociological approach. They were entered into the FloVegSi database (Fauna, Flora, Vegetation and Paleovegetation of Slovenia) of the Jovan Hadži Institute of Biology at ZRC SAZU (Seliškar et al. 2003) and processed using hierarchical classification, unweighted average linkage method - UPGMA and Wishart's similarity ratio. We transformed the combined cover-abundance values with numerical values (1-9) according to van der Maarel (1979). Numerical comparisons were performed with the SYN-TAX 2000 program package (Podani 2001). The nomenclatural source for the names of vascular plants were the Mala flora Slovenije (Martinčič et al. 2007) and Flora alpina (Aeschimann et al. 2004a,b). Ros et al. (2007) was the nomenclatural source for the names of liverworts (Marchantiophyta) and Ros et al. (2013) for the names of mosses. Steiner (1993), Zechmeister (1993), Tomaselli et al. (2011), Šilc \& Čarni (2012), Mucina et al. (2016) and Hinterlang (2017) served as nomenclatural sources for the names of the syntaxa. The data source for the geological bedrock was Buser (2009). The geographic coordinates of the relevés were determined based on the Slovenian geographic coordinate system D 48 (Zone 5) on the Bessel ellipsoid and with Gauss-Krüger projection.

\section{Results}

\section{New localities of Carex frigida and its currently known distribution in Slovenia}

9547/4 (UTM 33TUM94) Slovenia: Primorska, Julian Alps, Loška Koritnica, V Mlakah to the west of Veliki Žleb under Mangart, $1750 \mathrm{~m}-1770 \mathrm{~m}$ a.s.l., wet rock wall and spring streams. Leg. \& det. I. Dakskobler, 
8. 9. 2004 and 12. 7. 2007, herbarium LJS, relevés 7 and 8 in Table 2. New locality in an already known quadrant.

9547/4 (UTM 33TUM94) Slovenia: Primorska, Julian Alps, Loška Stena, under Bavh, Pri Kamnih, wet rocks, 1910 m a.s.l. Det. I. Dakskobler, 17. 8. 2012, author's photographs, relevé 12 in Table 2. New locality in an already known quadrant.

9548/4 (UTM 33TVM04) Slovenia: Primorska, Julian Alps, Trenta, Mlinarica headwaters under Zadnje Plate, 1680 m a.s.l. Leg. \& det. I. Dakskobler, 6. 8. 2008, herbarium LJS, spring community with dominant Palustriella commutata and Saxifraga stellaris subsp. alpigena, which we are still studying, so this relevé was not included in Table 2, Carex frigida is rare (+) here. New locality in the new quadrant.

9646/4 (UTM 33TUM83) Slovenia: Primorska, Julian Alps, Kanin Mts. Scree spring area to the west of Mali Babanski Skedenj, $1880 \mathrm{~m}$ a.s.l. Leg \& det. I. Dakskobler, 27. 7. 2020, herbarium LJS, relevé 11 in Table 2. New locality in the new quadrant.

9647/2 (UTM 33TUM93) Slovenia: Primorska, Julian Alps, Bala, Spodnji Lepoč, springs above or along the perimeter of the fen, 1690-1750 m a.s.l. Leg. \& det. I. Dakskobler, B. Vreš, B. Anderle \& A. Trnkoczy, 13. 7. 2007 and I. Dakskobler, 7. 8. 2020, herbarium LJS, relevés 15, 16 and 17 in Table 2. New locality in the new quadrant.

9649/1 (UTM 33TVM13) Slovenia: Gorenjska, Julian Alps, Triglav mountain range, Konjska planina under Cesar, 2020 m a.s.l., headwaters. Leg. \& det. B. Zupan, S. Behrič \& I. Dakskobler, 1. 8. 2019, herbarium LJS, relevé 18 in Table 2. New locality in an already known quadrant.

9849/2 (UTM 33TVM11) Slovenia: Primorska, foothills of the Julian Alps, Mt. Porezen, under the village of Porezen, Prodarjeva Grapa gorge, wet rocks in the spring area, $460 \mathrm{~m}-510 \mathrm{~m}$ a.s.l. Leg. \& det. I. Dakskobler, 9. 5. 2020 and 13. 6. 2020, herbarium LJS. The lowest

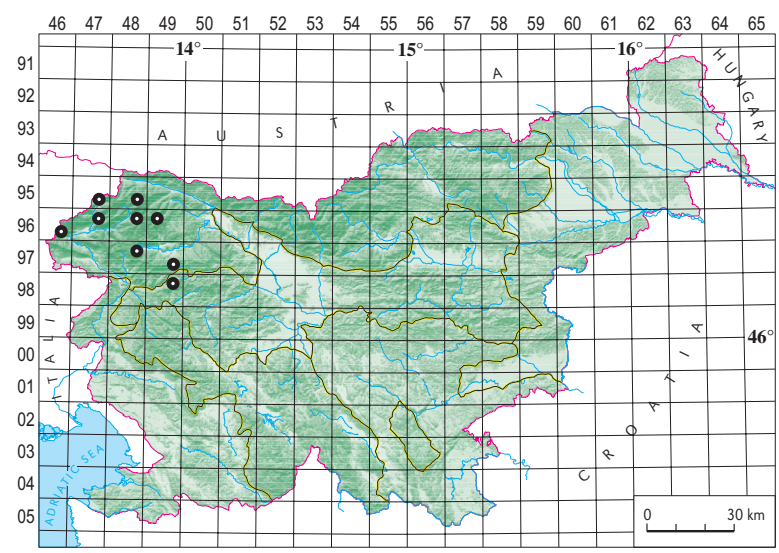

Figure 1: Distribution of Carex frigida in Slovenia. Slika 1: Razširjenost vrste Carex frigida v Sloveniji. locality of this sedge in Slovenia (a special community of Carex frigida, Pinguicula vulgaris, Molinia arundinacea, Carex flacca, Palustriella commutata and other species will be discussed in a separate article). New locality in the new quadrant.

\section{Communities with Carex frigida}

In Austria, Steiner (1993: 155-156) reports only the association Caricetum frigidae Rübel 1911 (which according to him comprises also the stands of associations TofieldioCaricetum frigidae Oberdorfer 1956 and Eriophoro-Caricetum frigidae Oberdorfer 1956). Carex frigida is a character species of the association and its constant companions are Campylium stellatum, Carex flava, C. nigra, Deschampsia cespitosa, Scorpidium revolvens (Drepanocladus revolvens), Eleocharis quinqueflora, Eriophorum angustifolium and Trichophorum cespitosum. Steiner classifies this association into the alliance Caricion davallianae, order Caricetalia davallianae and class Scheuchzerio-Caricetea fuscae.

Zechmeister (1993: 229) describes the association Cratoneuretum falcati Gams 1927 with diagnostic species Cratoneurum falcatum, Philonotis calcarea, Silene pudibunda (Heliosperma pusillum subsp. pudibundum), Silene pusilla (Heliosperma pusillum subsp. pusillum), a differential species Persicaria vivipara (Polygonum viviparum) and dominating and constant species Saxifraga aizoides, Agrostis stolonifera, Bryum pseudotriquetrum (Ptychostomum pseudotriquetrum), Carex frigida, Epilobium alsinifolium, Poa alpina, Ranunculus montanus and Saxifraga stellaris subsp. robusta.

In Germany, Hinterlang (2017) reports Carex frigida as differential species of the order Montio-Cardaminetalia in communities of alliances Philonotidion seriatae and Cratoneurion commutati.

According to him (Hinterlang, ibid.), diagnostic species of the alliance Cratoneurion commutati include character species Philonotis calcarea, Aneura pinguis, Bryum turbinatum, Preissia quadrata and differential species Pinguicula alpina, P. vulgaris and Cratoneuron commutatum (as character species of the class Montio-Cardaminetea). He mentions four associations from this alliance. One of them, Cardamino-Cratoneuretum Kornas \& Medwecka-Kornas 1967, comprises also Carex frigida. Differential species of this association are Philonotis calcarea, Calycocorsus stipitatus, Bryum turbinatum, Carex dioica, Triglochin palustre, Carex flava, Equisetum palustre, Molinia caerulea, Tussilago farfara and Carex frigida.

In the Grison Alps in the Swiss canton of Graubünden, Braun-Blanquet (1971: 33-36) described the association Saxifrago aizoidis-Caricetum frigidae Braun-Blanquet 1971, which is known also in the Alpine region of France, 
where the association Caltho palustris-Caricetum frigidae Julve 2007 was also reported (eVeg, 2020).

Tomaselli et al. (2011) in the Fassa Dolomites (Trentino, SE Alps) recorded Carex frigida in the stands of the associations Cratoneuretum falcati (frequency 7\%), Montio-Bryetum schleicheri (frequency 5\%) and Blindio-Scapanietum undulatae (frequency 25\%).

E. and S. Pignatti (2016) mention Carex frigida only as an accidental species of associations Cratoneuretum commutati (one relevé) and Cratoneuretum falcati (two relevés).

\section{Syntaxonomic classification of the studied communities and site descriptions}

We made 24 relevés and arranged them in Table 2 . We omitted two relevés in which we recorded Carex frigida, but were unable to find support material for them in the working herbarium of the Institute of Biology of the ZRC SAZU, Regional Unit Tolmin. Both relevés comprise stands that are dominated by Carex ferruginea (Caricetum ferrugineae s. lat.) and are located in the regions where Carex frigida was recorded on other sites and documented with herbarium specimens or photographs:

9548/4: Trenta, Mlinarica spring area under Zadnje Plate, grassland along a spring stream, $1720 \mathrm{~m}$ a.s.l. Relevé I. Dakskobler, 31.8. 2009.

9547/4: Bala Valley, Loška Stena, a wet gully on the sunny side of the ridge towards Plešivec, $2070 \mathrm{~m}$ a.s.1., tall herbs in the gully (with dominating Carex ferruginea and Peucedanum ostruthium). Relevé and photograph of the stand I. Dakskobler, 17. 8. 2012.
The relevés were arranged in Table 2 based on the results of hierarchical classification (Figure 2).

In the main, the relevés formed two distinct clusters. The relevés on the right side of the dendrogram are from Blehe under Šoštar (at Črna Prst). When we first published their table (excluding moss species) we classified them into the provisional association Carici frigidae-Petasitetum albi nom. prov. (Dakskobler 2003). At the time we gave the following description of the site of its stands: a gully above and along the source of a small stream at around $1370 \mathrm{~m}-1400 \mathrm{~m}$ a.s.l., tall herb communities on the scree slope in the gully and on small, unstable landslide sites along its edge. Shaly claystone (perhaps siltstone) with admixture of chert predominates, and scree is admixed with limestone (which predominates at slightly higher elevations; the source is connected with the contact of geological layers).

Determination of mosses collected at the time demonstrated that most of the relevés are dominated by Bryum pseudotriquetrum (Ptychostomum pseudotriquetrum) and Brachythecium rutabulum, Cratoneuron filicinum occurs in two relevés and one relevé comprises also several other species diagnostic for the class Montio-Cardaminetea: Palustriella commutata, Philonotis fontana, Didymodon vinealis, Calliergonella cuspidata and Brachythecium rivulare. Other determined mosses, many of which are acidophilic, include rare species Rhabdoweisia fugax and Pogonatum nanum, whose localities had not previously been reported in the Slovenian part of the Julian Alps (Martinčič 2003). The only known localities of Rhabdoweisia fugax (altogether 17) are in Eastern Slovenia, in the eastern Karawanks, Kamnik-Savinja Alps, Pohorje mountain range, Dravski Kozjak and on Strojna. Pogonatum

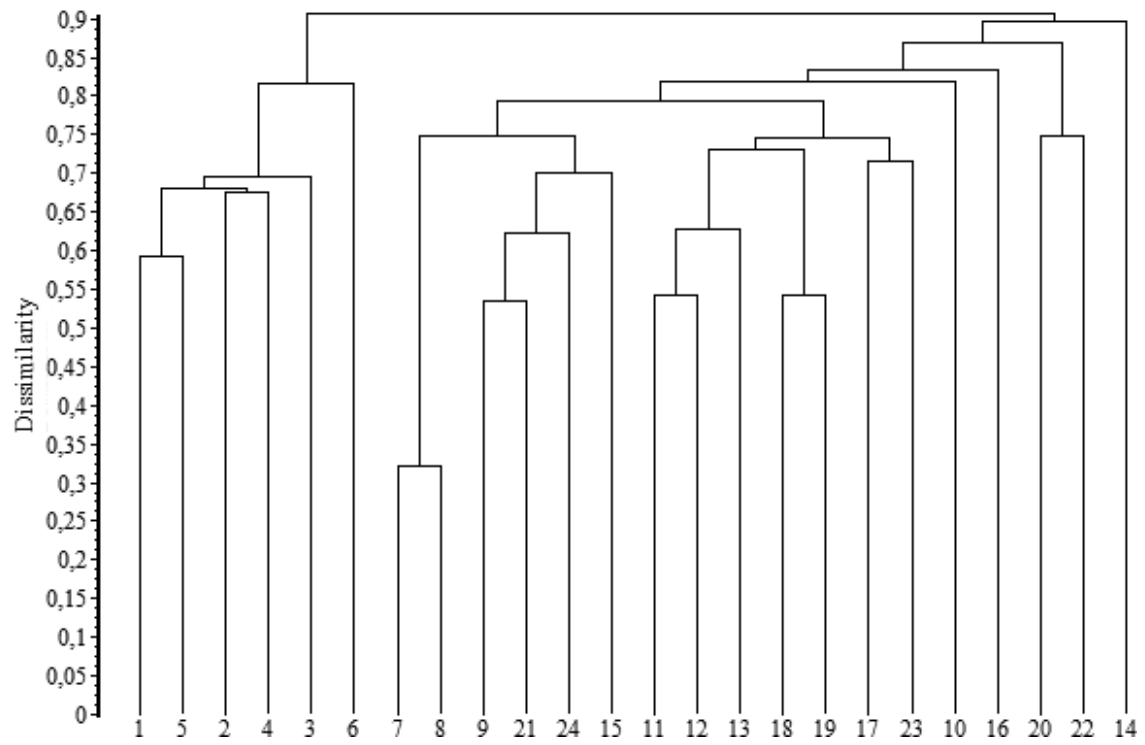

Figure 2: Dendrogram of relevés with Carex frigida in the Julian Alps (UPGMA, 1 - similarity ratio). Slika 2: Dendrogram popisov sestojev z vrsto Carex frigida v Julijskih Alpah (UPGMA, 1 - similarity ratio). 
nanum, on the other hand, has more localities in all phytogeographic units of Slovenia other than the Julian Alps (A. Martinčičs database). Both species are acidophilic, with boreal-montane distribution.

In terms of their constancy and mean cover the listed mosses do not justify the classification of this community into the class Montio-Cardaminetea, so we can confirm its original classification into the association Carici frigidae-Petasitetum albi (Dakskobler 2003) Dakskobler et Martinčič ass. nov. hoc loco (relevés 2-6 in Table 2). Its diagnostic species are Petasites albus, Carduus carduelis, Heracleum sphondylium subsp. pollinianum, Senecio ovatus (S. fuchsii) and Carex frigida. The nomenclatural type, holotypus, of the new association is releve 4 in Table 2. The association is classified into the alliance Adenostylion alliariae and class Mulgedio-Aconitetea. Relevé 1 in Table 2 from the same locality is classified into the association Saxifrago aizoidis-Caricetum ferrugineae Dakskobler 1996 (Dakskobler 2003). It is characterised by Cynodontium fallax, a rare acidophilic moss included on the Red List as endangered (EN) (Martinčič 2016). Its previously known localities in Slovenia were in the Pohorje mountain range (between Vitanje and Rakovec, Bukovje at Pukštajn), in the eastern Karawanks (valley of the Bistra River and Uršlja Gora) and on Košenjak (the Velka valley at Lapanova Stena) - Martinčič (2018). The herbarium features also specimens from Grom's herbarium (incorrectly classified as Cnestrum schisti) from the Mežica Valley, but does not provide the exact locality (A. Martinčičs database). It grows on wet, shady silicate rocks in the montane, rarely also subalpine belt (at $500 \mathrm{~m}-1500 \mathrm{~m}$ a.s.l.).

In terms of species composition, relevés 7-21 in Table 2 cannot be classified into any of the above listed associations named after Carex frigida, because they obviously do not have enough species in common. Floristic similarity with the stands of the association Saxifrago aizoidisCaricetum frigidae according to Sørensen (1948) is only 28.5\% (see also Table 1 and Figures 3 and 4).

Our stands also have only a few species in common with the stands of the association Cardamino-Cratoneuretum: Carex frigida, Cratoneuron commutatum (Palustriella commutata), Tussilago farfara, Soldanella alpina, Bryum pseudotriquetrum (Ptychostomum pseudotriquetrum), Epilobium alsinifolium, Palustriella decipiens, Cardamine amara, Deschampsia cespitosa, Carex nigra, Juncus articulatus.

If we compare the diagnostic species of classes MontioCardaminetea and Scheuchzerio-Caricetea fuscae, whose stands usually comprise Carex frigida, the species of the class Montio-Cardamineted are more numerous and have higher mean cover, especially considering that Carex frigi$d a$ is not only a character species of the order Caricetalia davallianae, but occurs also in the communities of the alliance Cratoneurion commutati.

The following diagnostic species of the class MontioCardaminetea and in particular of the alliance Cratoneurion frequently occur in our stands: Palustriella commutata, P. decipiens, Bryum pseudotriquetrum (Ptychostomum pseudotriquetrum), Cratoneuron filicinum, Saxifraga aizoides and Epilobium alsinifolium. Heliosperma pusillum and Preissia quadrata (which are diagnostic also for the alliance Cystopteridion s. lat.) can also be considered diagnostic for this class and alliance. In addition to Carex frigida, the more frequent species of the order Caricetalia davallianae and class Scheuchzerio-Caricetea fuscae in our stands include only Parnassia palustris, Carex capillaris, Campylium stellatum and Calliergonella lindbergii.

Species of the order Arabidetalia caeruleae (most frequently Veronica alpina, Soldanella alpina, Salix retusa and Trifolium pallescens), class Thlaspietea rotundifolii (the most frequent are Festuca nitida, Achillea atrata, Adenostyles glabra and Rhodiola rosea), alliance Caricion ferrugineae (Carex ferruginea, Cerastium subtriflorum, Gentiana pumila), order Seslerietalia coeruleae and class Elyno-Seslerietea (Galium anisophyllum, Aster bellidiastrum, Polygonum viviparum, Myosotis alpestris), class Mulgedio-Aconitetea (Viola biflora, Aconitum lycoctonum s. lat., Peucedanum ostruthium), class Juncetea trifidi s. lat. (Festuca nigrescens, Euphrasia minima, Juncus jacquinii), and order Poo alpinae-Trisetetalia, class Molinio-Arrhenatheretea (Poa alpina, Crepis aurea, Deschampsia cespitosa), are quite evenly represented in other phytosociological groups. Species diversity is therefore considerable, but the site description, on the other hand, is very similar. These are mainly communities along small springs in the subalpine and alpine belt (1690-2050 m a.s.l.), stands along running cold waters, on gravelly or rocky sites, where limestone (rarely dolomite) is frequently admixed with marlstone and in places also with chert.

We find that the most appropriate classification of these stands is into the alliance Cratoneurion commutati, order Montio-Cardaminetalia and class Montio-Cardaminetea. Admittedly, our relevés do not meet all the criteria for the classification into the alliance Cratoneurion (Zechmeister 1993: 229): sunny springs, water contains a high concentration of oxygen and calcium ions, mosses (cryptogams) almost never cover less than a half of the site area and vascular plants usually do not cover more than a third; nevertheless, we find that classifying them into any other alliance is even less justified.

Two associations from this alliance have been documented with a phytosociological table for the territory of Slovenia and its immediate vicinity: Cratoneuretum commutati Aichinger 1933 (Aichinger 1933: 64-65) and 
Cratoneuretum falcati Gams 1927 (Surina 2005a, b). Previously (Martinčič 2003), the taxon Palustriella falcata was discussed only at the rank of variety Palustriella commutata var. falcata, and only since recently (Martinčič 2014) as an independent species Palustriella falcata. Although at higher elevations taxon $P$. falcata generally replaces taxon P. commutata (Surina 2005b: 102), this is not supported by the list of localities in the Karawanks (Martinčič 2014: 336). The highest locality of taxon $P$. commutata is Mt. Stol (2000 m a.s.l.), and Pusti Rovt under Korenščica (1500 m a.s.l.) is the highest locality of taxon $P$. falcata.

We made a synoptic table (Table 1) with four columns that comprise our community as well as the stands of both previously listed associations and stands of the asso-

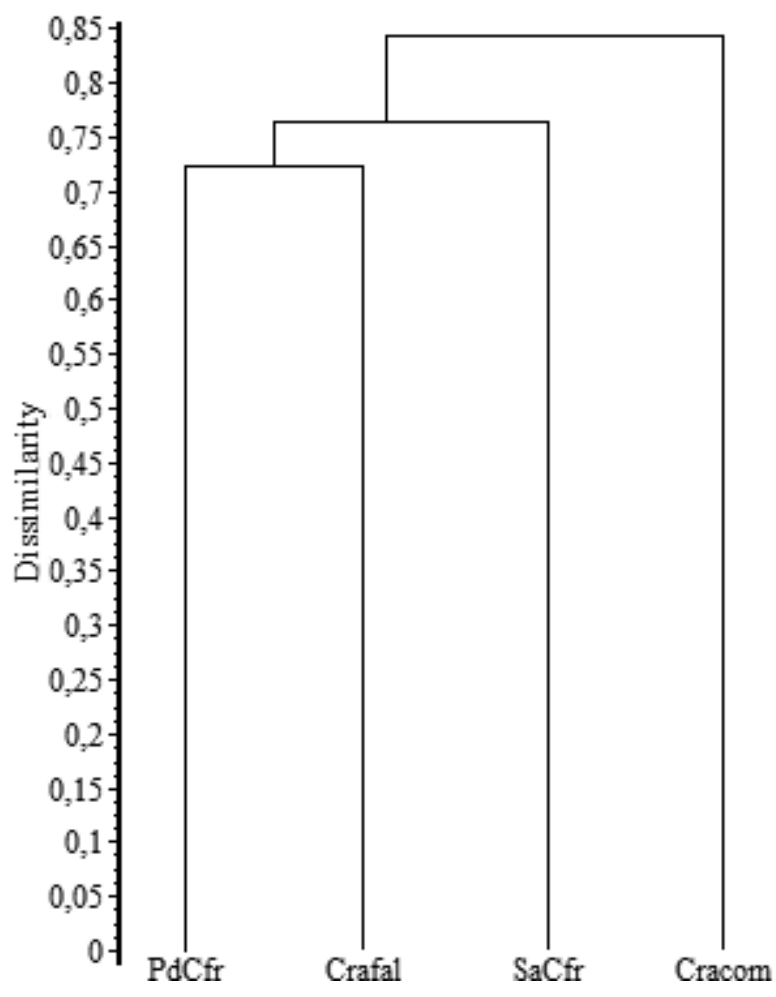

Legend (Legenda):

PdCfr Palustriello decipientis-Caricetum frigidae, Julian Alps, this article

Crafal Cratoneuretum falcati, Julian Alps, Krn Mountains, Surina (2005a, Table 1)

SaCfr Saxifrago aizoidis-Caricetum frigidae, Rätischen Alps, Braun-Blanquet (1971, Table 8)

Cracom Cratoneuretum commutati, Karavanke, Aichinger (1933, Table 17)

Figure 3: Dendrogram of four communities of mountain springs in the Alps (UPGMA, 1 - similarity ratio).

Slika 3: Dendrogram štirih združb gorskih povirij v Alpah (UPGMA, 1 - similarity ratio). ciation Saxifrago aizoidis-Caricetum frigidae (Braun-Blanquet 1971). Taxon $P$. commutata and taxon $P$. falcata were treated as a single species. We obtained two dendrograms, which differ slightly if we take into account species constancy (Figure 3) or merely presence/absence of species (Figure 4).

In terms of species constancy our relevés are the most similar to the relevés of the association Cratoneuretum falcati from the Krn Mountains, but if we take into account only the presence or absence of species they are more similar to the stands of the association Saxifrago aizoidisCaricetum frigidae. In both cases, however, floristic similarity is too low to allow us to classify them into either of these associations.

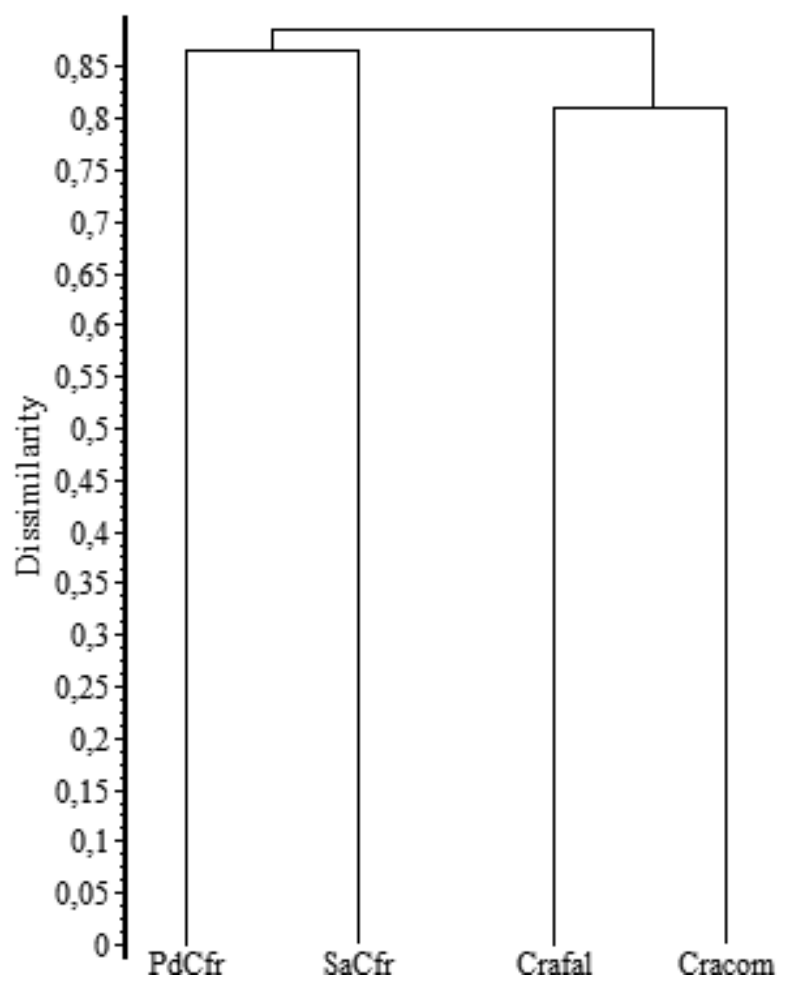

Legend (Legenda): - see Figure 3

Figure 4: Dendrogram of four communities of mountain springs in the Alps (UPGMA, 1 - Jaccard).

Slika 4: Dendrogram štirih združb gorskih povirij v Alpah (UPGMA, 1 - Jaccard).

Likewise, the recorded stands cannot be classified into the association Cratoneuretum falcati, because in terms of mean cover Palustriella commutata (Cratoneuron commutatum s. lat.) dominates over Carex frigida only in several stands. In our case, it is therefore more appropriate to use the species that dominate the herb layer as 
the name-giving species of the association. The recorded stands are classified into the new association Palustriello decipientis-Caricetum frigidae ass. nov. hoc loco. Diagnostic (character and differential) species of the association are Carex frigida, Palustriella decipiens, Festuca nitida (the southeast-European montane species of wet screes), Achillea atrata, Carex ferruginea and Paederota lutea (southeastern-Alpine-north-Dinaric chasmophytic species). Palustriella decipiens is a Eurasiatic, boreal-montane moss that is preferentially encountered on calcareous micaschists in crenic waters with low mineral content (Dierßen 2001). It must also survive more severe climates than Palustriella commutata (Tomaselli et al. 2011). It is diagnostic of the order Montio-Cardaminetalia (Hinterlang 2017). In Slovenia, it was recorded in the Julian Alps, the Karawanks and in the Kamnik-Savinja Alps, only rarely in their foothills and (in) the Dinaric Alps. It grows in the subalpine and alpine belt, up to $2100 \mathrm{~m}$ a.s.l. Some of its localities are also in the montane and submontane belt, descending as low as $480 \mathrm{~m}$ a.s.l. (Višče near Lake Bled), $460 \mathrm{~m}$ a.s.l. (Brdo pri Kranju, near the Vršek rivulet), 450 m a.s.l. (under Komar near Koritno), $300 \mathrm{~m}$ a.s.l. (Spodnje Pirniče under Šmarna Gora, warm spring), $200 \mathrm{~m}$ a.s.l. (the left bank of the Idrijca River near Stopnik) and even $80 \mathrm{~m}$ a.s.l. (the left bank of the Soča River near Deskle). It sites are moist to wet: fens, cold springs, wet rocks with splashed water, rarely meadows (Martinčič 2003, A. Martinčičs database). In the upper montane belt of the Fassa Dolomites (Trentino, SE Alps) a spring community named phytocoenon of Palustriella decipiens was described (Tomaselli et al., ibid.).

The nomenclatural type, holotypus, of the new association is relevé 10 in Table 2 . Two variants can be distinguished: var. Heliosperma pusillum (relevés 7-14 in Table 2, stands are more typical for cold springs, the differential species of the variant is also Cerastium subtriflorum) and var. Veronica alpina (relevés 15-21, which are slightly more similar to fen communities from the alliance Caricion davallianae or in contact with them, the differential species of the variant is also Gentiana pumila).

Relevés 22 and 23 in Table 2 (under Mangart, $\mathrm{Na}$ Jami) are provisionally classified into the subassociation Ranunculo traunfellneri-Paederotetum luteae Surina 2005 caricitosum frigidae nom. prov. and alliance Cystopteridion. Blinda caespiticia, which is included in the Red List as endangered (EN) (Martinčič 2016) was also identified in one of the relevés. Relevé 24 (Malo Polje at Velo Polje) belongs to the association Caricetum davallianae s. lat. (Equiseto palustris-Caricetum davallianae nom. prov.), alliance Caricion davallianae, order Caricetalia davallianae and class Scheuchzerio-Caricetea fuscae.

\section{Conspectus of the syntaxa described herein, ordered in a syntaxonomic scheme:}

Montio-Cardaminetea $\mathrm{Br}$-Bl. et Tx. ex Klika et Hadač 1944

Montio-Cardaminetalia Pawłowski et al. 1928

Cratoneurion commutati Koch 1928

Palustriello decipientis-Caricetum frigidae Dakskobler et Martinčič 2021

var. Heliosperma pusillum

var. Veronica alpina

Scheuchzerio palustris-Caricetea nigrae Tx. 1937 nom. mut.

Caricetalia davallianae Br.-Bl. 1950 nom. conserv. propos.

Caricion davallianae Klika 1934

Caricetum davallianae Dutoit 1924 s. lat. (Equiseto

palustris-Caricetum davallianae nom. prov.)

Asplenietea trichomanis (Br.-Bl. in Meier et Br.-Bl. 1934)

Oberd. 1977

Potentilletalia caulescentis Br.-Bl. in Br.-Bl. et Jenny 1926

Cystopteridion fragilis Richard 1972 s. lat.

Ranunculo traunfellneri-Paederotetum luteae

Surina 2005

caricetosum frigidae nom. prov.

Mulgedio-Aconitetea Hadač et Klika in Klika et Hadač 1944

Adenostyletalia alliariae Br.-Bl. 1930

Adenostylion alliariae Br.-Bl. 1926

Carici frigidae-Petasitetum albi (Dakskobler 2003)

Dakskobler et Martinčič 2021

\section{Conclusions}

Carex frigida is rare in Slovenian flora and its localities in the montane to the alpine belt $(900 \mathrm{~m}-2070 \mathrm{~m})$ have previously been reported only in the Julian Alps. In our research we confirmed most of the previously known localities and found several new ones (the spring area of the Mlinarica, Loška Stena: Bavh, Spodnji Lepoč, Konjska Planina under Cesar in the Triglav range, Mali Babanski Skedenj in the Kanin Mountains, Prodarjeva Grapa gorge on the northern side of Mt. Porezen, 460-510 m a.s.l, the lowest locality in Slovenia). We made relevés of the stands with this hygrophilous sedge and after identifying the collected mosses we were able to classify the studied communities using a syntaxonomic system. We confirmed and typified the previously described association Carici frigidae-Petasitetum albi at the altimontane spring at the contact of geological layers (claystone/siltstone with admixture of chert and limestone) in Blehe under Šoštar at Črna Prst. These stands are characterised by rare mosses, which until now had no known localities in the Slovenian part 
of the Julian Alps: Rhabdoweisia fugax, Pogonatum nanum and Cynodontium fallax (the latter occurs in a stand of the contact association Saxifrago aizoidis-Caricetum ferrugineae). Most of the other stands were recorded along small springs, on gravelly or rocky sites, where limestone (rarely dolomite) is frequently admixed with marlstone and in places also with chert. Some relevés belong to a chasmophytic (Ranunculo traunfellneri-Paederotetum luteae) or fen community Caricetum davallianae s. lat. The relevés with Carex frigida as the dominating vascular plant were classified into the new association Palustriello decipientis-Caricetum frigidae, whose diagnostic species are Carex frigida, Palustriella decipiens, Festuca nitida, Achillea atrata, Carex ferruginea and Paederota lutea. As the moss cover is abundant and dominated by species characteristic for the class Montio-Cardaminetea (Palustriella commutata, P. decipiens, Cratoneuron filicinum and Bryum pseudotriquetrum / Ptychostomum pseudotriquetrum), as well as several vascular plants characteristic for mountain spring communities (Saxifraga aizoides, Epilobium alsinifolium, Heliosperma pusillum), are presented, these stands can be classified into the alliance Cratoneurion. This was confirmed also by the comparison with previously described communities from this alliance in Slovenia, mainly with stands of the association Cratoneuretum falcati from the Krn Mountains. Because of low floristic similarity (Sørensen's similarity index, Sørensen 1948, is 28.5\%) they cannot be classified into the association Saxifrago aizoidisCaricetum frigidae, which is described in the Grison Alps of the Swiss canton Graubünden and reported also in the French Alps.

Stands with Carex frigida in the Julian Alps can mainly be classified into the Natura 2000 habitat type $7220^{*}$ (Physis code 54.12) Petrifying springs with tufa formation (Cratoneurion). They are a habitat of several protected vascular plants (Anon. 2004): Gentiana lutea subsp. symphyandra, Gymnadenia conopsea, Pinguicula alpina, P. vulgaris, red-listed vascular plants (Anon. 2002): Carex bicolor, C. davalliana, C. frigida, Eriophorum scheuchzeri, Trifolium thalii, and red-listed mosses (Martinčič 2016): Blinda caespiticia and Cynodontium fallax. According to our findings, these communities are not threatened, despite occasional grazing of small ruminants (sheep) in the vicinity, e.g. under Mangart, Bavh, on Konjska Planina and at Spodnji Lepoč. Although some of the stands under Mangart are in the immediate vicinity of mountain trails (Na Jami), most of them are well off the beaten tracks, in particular the spring in Blehe under Ššstar and the fen at Spodnji Lepoč above Bala. Nevertheless, all of the described springs are indirectly threatened by climate change as a result of less snowfall and precipitation in general.

\section{Povzetek}

\section{Združbe z vrsto Carex frigida $\mathbf{v}$ Julijskih Alpah (severozahodna Slovenija)}

Carex frigida je redka vrsta v flori Slovenije, z do zdaj znanimi nahajališči od montanskega do alpinskega pasu (900 m do 2070 m) le v Julijskih Alpah. Pri naših raziskavah smo potrdili večino do zdaj znanih nahajališč in našli še nekaj novih (povirje Mlinarice, Loška stena: Bavh, Spodnji Lepoč, Konjska planina pod Cesarjem v Triglavskem pogorju, Babanski Skedenj v Kaninskem pogorju, Prodarjeva grapa pod Poreznom z nadmorsko višino 460 do $510 \mathrm{~m} \mathrm{~nm}$. v., do zdaj najnižje ležeče nahajališče v Sloveniji). Sestoje, v katerih uspeva ta vlagoljubni šaš, smo fitocenološko popisali in ko nam je uspelo določiti na popisih nabrane mahove, smo proučene združbe lahko uvrstili v sintaksonomski sistem. Potrdili in tipizirali smo že pred leti opisano asociacijo Carici frigidae-Petasitetum albi pri altimontanskem izviru na stiku geoloških plasti (glinavec / meljevec s primesjo roženca in apnenec) v Blehah pod Šoštarjem pri Črni prsti. Posebnost teh sestojev so redke mahovne vrste, ki v slovenskem delu Julijskih Alp do zdaj niso imele znanih nahajališč: Rhabdoweisia fugax, Pogonatum nanum in Cynodontium fallax (slednja uspeva v sestoju stične asociacije Saxifrago aizoidis-Caricetum ferrugineae). Večino ostalih sestojev smo popisali ob majhnih izvirih, na gruščnatih ali skalnatih rastiščih, kjer je apnencu (redkeje dolomitu) pogosto primešan laporovec ali ponekod tudi roženec, $v$ subalpinskem in alpinskem pasu na nadmorski višini od 1690 do $2050 \mathrm{~m}$. Nekateri popisi sodijo v združbo skalnih razpok (Ranunculo traunfellneri-Paederotetum luteae), ali nizkobarjansko združbo Caricetum davallianae s. lat. Popise, v katerih je med cevnicami prevladujoča vrsta Carex frigida pa smo uvrstili v novo asociacijo Palustriello decipientis-Caricetum frigidae, katere diagnostične vrste so Carex frigida, Palustriella decipiens, Festuca nitida, Achillea atrata, Carex ferruginea in Paederota lutea. Po dobro zastopani mahovni plasti s prevladujočimi vrstami, značilnimi za razred Montio-Cardaminetea: Palustriella commutata, P. decipiens, Cratoneuron filicinum in Bryum pseudotriquetrum (Ptychostomum pseudotriquetrum), a tudi z nekaterimi za združbe gorskih izvirov značilnimi cevnicami Saxifraga aizoides, Epilobium alsinifolium, Heliosperma pusillum, te sestoje lahko uvrstimo v zvezo Cratoneurion. To je potrdila tudi primerjava z nekaterimi do zdaj opisanimi združbami iz te zveze v Sloveniji, predvsem s sestoji asociacije Cratoneuretum falcati iz Krnskega pogorja. Uvrstitev v asociacijo Saxifrago aizoidis-Caricetum frigidae, ki je opisana v švicarskih Alpah in jo poznajo tudi v francoskih Alpah, zaradi zelo majhne floristične podobnosti (le $28,5 \%$ po Sørensenu 1948) ni mogoča. 
Sestoje z mrzlim šašem v Julijskih Alpah večinoma lahko uvrstimo v Natura 2000 habitatni tip 7220* (Physis koda 54.12) Lehnjakotvorni izviri (Cratoneurion). V njih uspevajo nekatere zavarovane cevnice (Anon. 2004): Gentiana lutea subsp. symphyandra, Gymnadenia conopsea, Pinguicula alpina, $P$. vulgaris in nekatere vrste iz rdečega seznama cevnic (Anon. 2002): Carex bicolor, C. davalliana, C. flavella, C. frigida, Eriophorum scheuchzeri, Trifolium thalii ter iz rdečega seznama mahov (Martinčič 2016): Blinda caespiticia in Cynodontium fallax. Po naših spoznanjih za zdaj te združbe niso ogrožene, čeprav je občasno v okolici prisotna paša drobnice (ovac) - na primer pod Mangartom, Bavhom, na Konjski planini in v Spodnjem Lepoču. Nekateri sestoji pod Mangartom so zelo blizu planinskih poti ( $\mathrm{Na}$ jami), ostali so večinoma odmaknjeni od bolj obljudenih poti. Še posebej to velja za izvir v Blehah pod Šoštarjem, prav tako za nizko barje Spodnji Lepoč in njegovo obrobje nad Balo. Posredno pa vse opisane izvire ogrožajo podnebne spremembe z vedno manjšo količino snežnih padavin in padavin na sploh.

\section{Acknowledgements}

We would like to thank the heirs of late Tone Wraber for giving his manuscripts and professional literature to the safekeeping of the Botanical Garden of the University of Ljubljana, and to its director, Dr. Jože Bavcon, who allowed us to examine professor's legacy. Dr. Branko Vreš, Branko Zupan, Brane Anderle, Dr. Amadej Trnkoczy, Sanja Behrič and late Vid Dakskobler helped us in the field work, and Prof. Dr. Urban Šilc and Dr. Dirk Hinterlang with literature sources. Two anonymous reviewers offered valuable improvements and corrections. We also acknowledge the financial support from the Slovenian Research Agency (research core funding No. P1-0236). English translation by Andreja Šalamon Verbič.

\section{References - Literatura}

Aeschimann, D., Lauber, K., Moser, D. M. \& Theurillat, J.-P. 2004a: Flora alpina. Bd. 1: Lycopodiaceae-Apiaceae. Haupt Verlag, Bern, Stuttgart, Wien, 1159 pp.

Aeschimann, D., Lauber, K., Moser, D. M. \& Theurillat, J.-P. 2004b: Flora alpina. Bd. 2: Gentianaceae-Orchidaceae. Haupt Verlag, Bern, Stuttgart, Wien, 1188 pp.

Aichinger, E. 1933: Vegetationskunde der Karawanken. Gustav Fischer, Jena 329 pp.

Anonymous 2002: Pravilnik o uvrstitvi ogroženih rastlinskih in živalskih vrst v rdeči seznam. Uradni list RS 82/2002.

Anonymous 2004: Uredba o zavarovanih prosto živečih rastlinskih vrstah. Uradni list RS 46/2004.
Braun-Blanquet, J. 1964: Pflanzensoziologie. Grundzüge der Vegetationskunde. 3. Auflage. Springer,. Wien - New York, 865 pp.

Braun-Blanquet, J., 1971: Übersicht der Pflanzengesellschaften der Rätischen Alpen im Rahmen ihrer Gesamtverbreitung. III: Flachmoorgesellschaften (Scheuchzerio-Caricetea fuscae). Veröff. Geobot. Inst. Rübel, 46: 1-70.

Buser, S. 2009: Geološka karta Slovenije $1: 250.000$. Geological map of Slovenia $1: 250,000$. Geološki zavod Slovenije, Ljubljana.

Dakskobler, I. 2003: Floristične novosti iz Posočja in sosednjih območij v zahodni Sloveniji - III. Hladnikia 15-16: 43-71.

Dierßen, K. 2001: Distribution, ecological amplitude and phytosociological characterization of European bryophytes. Bryophytorum Bibliotheca Band 56. Cramer, Berlin, 289 pp.

eVeg, 2020: Une base de données pour les végétations d'Europe. Available from: https://www.e-veg.net/accueil.

Hartl, H., Kniely, G., Leute, G. H., Niklfeld, H., Perko, M. 1992: Verbreitungsatlas der Farn- und Blütenpflanzen Kärntens. Naturwissenschaftlicher Verein für Kärnten, Klagenfurt, 451 pp.

Hinterlang, D. 2017: Montio-Cardaminetea (C6) Quell- und Waldsumpfgesellschaften - Synopsis der Pflanzengesellschaften Deutschlands. Heft 12, Göttingen, 110 pp.

Jogan, N., Bačič, T., Frajman, B., Leskovar, I., Naglič, D., Podobnik, A., Rozman, B., Strgulc - Krajšek, S. \& Trčak, B. 2001: Gradivo za Atlas flore Slovenije. Center za kartografijo favne in flore, Miklavž na Dravskem polju, 443 pp.

Maarel, van der E. 1979: Transformation of cover-abundance values in phytosociology and its effects on community similarity. Vegetatio 39 (2): 97-114

Marchesetti, C. 1879: Una passeggiata alle Alpi Carniche. Boll. Soc. Adr. Sci. Nat., Trieste 4.

Martinčič, A. 2003: Seznam listnatih mahov (Bryopsida) Slovenije. Hacquetia 2 (1): 91-166.

Martinčič, A. 2007: Cyperaceae - ostričevke. In: Martinčič, A. (ed.): Mala flora Slovenije. Ključ za določanje praprotnic in semenk.

Tehniška založba Slovenije, četrta, dopolnjena in spremenjena izdaja, Ljubljana, pp. 793-821.

Martinčič, A. 2014: Mahovna flora fitogeografskega podobmočja Karavanke. Hacquetia 13 (2): 307-353.

DOI: https://doi.org/10.2478/hacq-2014-0009

Martinčič, A. 2016: Updated Red list of bryophytes of Slovenia. Hacquetia 15 (1): 107-126. DOI: https://doi.org/10.1515/hacq2016-0006

Martinčič, A. 2018: Novosti v flori mahov Slovenije 4. Hladnikia 42: 43-61.

Martinčič, A., Wraber, T., Jogan, N., Podobnik, A., Turk, B., Vreš, B., Ravnik, V., Frajman, B., Strgulc Krajšek, S., Trčak, B., Bačič, T., Fischer, M. A., Eler, K. \& Surina, B. 2007: Mala flora Slovenije. Ključ za določanje praprotnic in semenk. Četrta, dopolnjena in spremenjena izdaja. Tehniška založba Slovenije, Ljubljana, 967 pp.

Mucina, L., Bultmann, H., Dierssen, K., Theurillat, J.-P., Raus, T., Čarni, A., Šumberová, K., Willner, W., Dengler, J., Garcia, R. G., Chytrý, M., Hájek, M., Di Pietro, R., Iakushenko, D., Pallas, J., 
Daniëls, F. J. A., Bergmeier, E., Santos Guerra, A., Ermakov, N., Valachovič, M., Schaminée, J. H. J., Lysenko, T., Didukh, Y. P., Pignatti, S., Rodwell, J. S., Capelo, J., Weber, H. E., Solomeshch, A., Dimopoulos, P., Aguiar, C., Hennekens, S. M. \& Tichý, L. 2016: Vegetation of Europe: hierarchical floristic classification system of vascular plant, bryophyte, lichen, and algal communities. Applied Vegetation Science 19: 3-264. DOI: https://doi.org/10.1111/ avsc. 12257

Pignatti, E. \& Pignatti, S. 2016: Plant Life of the Dolomites. Vegetation Tables. Publication of the Museum of Nature South Tyrol Nr. 11, Bozen, Springer Verlag, Heidelberg, 575 pp.

Podani, J. 2001: SYN-TAX 2000. Computer Programs for Data Analysis in Ecology and Systematics. User's Manual, Budapest, 53 pp.

Poldini, L. 2002: Nuovo Atlante corologico delle piante vascolari nel Friuli Venezia Giulia. Regione Autonoma Friuli Venezia Giulia, Azienda Parchi e Foreste Regionali \& Universitá degli Studi di Trieste, Dipartimento di Biologia, Udine, 529 pp.

Ros, R. M., Mazimpaka, V., Abou-Salama, U., Aleffi, M., Blockeel, T.L., Brugués, M., Cano, M.J., Cros, R. M., Dia, M. G., Dirkse, G. M., El Saadawi, W., Erdağ, A., Ganeva, A., GonzálezMancebo, J. M., Hernstadt, I., Khalil, K., Kürschner, H., Lanfranco, E., Losada-Lima, A., Refai, M. S., Rodríguez-Nunez, S., Sabovljević, M., Sérgio, C., Shabbara, H., Sim-Sim, M. \& Söderström, M. 2007: Hepatics and Anthocerotes of the Mediterranean, an annotated checklist. Cryptogamie, Bryologie 28 (4): 351-437.

Ros, R.M., Mazimpaka, V., Abou-Salama, U., Aleffi, M., Blockeel, T.L., Brugués, M., Cros, R. M., Dia, M.G., Dirkse, G. M., Draper, I., El Saadawi, W., Erdağ, A., Ganeva, A., Gabriel, R., GonzálezMancebo, J.M., Hernstadt, I., Hugonnot, V., Khalil, K., Kürschner, H., Losada-Lima, A., Luís, L., Mifsud, S., Privitera, M., Puglisi, M., Sabovljević, M., Sérgio, C., Shabbara, H. M., Sim-Sim, M., Sotiaux, A., Tacchi, R., Vanderpoorten, A. \& Werner, O. 2013: Mosses of the Mediterranean, an annotated checklist. Cryptogamie, Bryologie 34 (2): 99-283.

Seliškar, T., Vreš, B. \& Seliškar, A. 2003: FloVegSi 2.0. Fauna, Flora, Vegetation and Paleovegetation of Slovenia. Computer programme for arranging and analysis of biological data. Biološki inštitut ZRC SAZU, Ljubljana.
Sørensen, Th. 1948: A method of establishing groups of equal amplitude in plant sociology based on similarity of species content. Det Kongelige Danske Videnskaberns Selskab, Biologiske Skrifter (København) 5 (4): 1-34.

Šilc, U. \& Čarni, A. 2012: Conspectus of vegetation syntaxa in Slovenia. Hacquetia 11 (1): 113-164. DOI: https://doi.org/10.2478/ v10028-012-0006-1

Steiner, G. M. 1993: Scheuchzerio-Caricetea fuscae. In: Grabherr, G. \& Mucina L. (eds.): Die Pflanzengesellschaften Österreichs. Teil II: Natürliche waldfreie Vegetation, Gustav Fischer Verlag, Jena - Stuttgart - New York, pp. 131-165.

Surina, B. 2005a: Contribution to the spring vegetation of the Julian Alps: the association Cratoneuretum falcati Gams 1927. Hacquetia 4: 52-59.

Surina, B. 2005b: Subalpinska in alpinska vegetacija Krnskega pogorja v Julijskih Alpah. Scopolia (Ljubljana) 57: 1-122.

Tomaselli, M., Spitale, D. \& Petraglia, A. 2011: Phytosociological and ecological study of springs in Trentino (south-eastern Alps, Italy). Journal of limnology 70 (Suppl. 1): 23-53. DOI: https://doi. org/10.4081/jlimnol.2011.s1.23

Wraber, T. 1967: Nekatere nove ali redke vrste v flori Julijskih Alp. Varstvo narave 5 (1966): 53-65.

Wraber, T. 1969: Nekatere nove ali redke vrste v flori Julijskih Alp (III). Varstvo narave 6: 73-84.

Wraber, T. 1983: Nekatere nove ali redke vrste v flori Julijskih Alp (V). Biološki vestnik 31 (2): 119-126.

Wraber, T. \& Skoberne, P. 1989: Rdeči seznam ogroženih praprotnic in semenk SR Slovenije. Varstvo narave 14-15: 1-429.

Zechmeister, H. 1993: Montio-Cardaminetea. In: Grabherr, G. \& Mucina L. (eds.): Die Pflanzengesellschaften Österreichs. Teil II: Natürliche waldfreie Vegetation, Gustav Fischer Verlag, Jena - Stuttgart - New York, pp. 213-240. 
Table 1: Synoptic table of some communities of mountain springs in the Alps

Preglednica 1: Sintezna tabela nekaterih združb gorskih izvirov v Alpah

\begin{tabular}{|c|c|c|c|c|c|}
\hline Successive number (Zaporedna številka) & & 1 & 2 & 3 & 4 \\
\hline Sign for syntaxa (Oznaka sintaksona) & & PdCfr & $\mathrm{SaCfr}$ & Crafal & Cracom \\
\hline Authors (Avtorji) & & IDAM & $\mathrm{BrBl}$ & BS & EA \\
\hline Number of relevé (Število popisov) & & 15 & 14 & 6 & 5 \\
\hline \multicolumn{6}{|l|}{ Montio-Cardaminetea } \\
\hline Palustriella commutata s. lat. (inc. var. falcata) & E0 & 60 & 43 & 100 & 100 \\
\hline Bryum pseudotriquetrum (Ptychostomum pseudotriquetrum) & E0 & 67 & . & . & . \\
\hline Palustriella decipiens & E0 & 67 & . & . & . \\
\hline Cratoneuron filicinum & E0 & 53 & . & . & . \\
\hline Epilobium alsinifolium & E1 & 47 & 7 & 67 & . \\
\hline Saxifraga aizoides & E1 & 40 & 93 & 50 & 40 \\
\hline Heliosperma pusillum & E1 & 40 & . & 67 & 20 \\
\hline Preissia quadrata & E0 & 13 & . & . & . \\
\hline Philonotis fontana & E0 & 13 & . & . & . \\
\hline Cardamine amara & E1 & 7 & 14 & . & . \\
\hline Hymenostylium recurvirostre & E0 & 7 & . & . & . \\
\hline Gymnostomum aeruginosum & E0 & 7 & . & . & . \\
\hline Campylidium calcareum & E0 & 7 & . & . & . \\
\hline Bryum schleicheri & E0 & 7 & . & . & . \\
\hline Conocephalum conicum & E0 & 7 & . & . & . \\
\hline Saxifraga stellaris subsp. alpigena (inc. subsp. robusta) & E1 & . & 43 & 50 & . \\
\hline Philonotis calcarea & E0 & . & 21 & 50 & . \\
\hline Philonotis seriata & E0 & . & 14 & . & . \\
\hline Eucladium verticillatum & E0 & . & . & . & 20 \\
\hline \multicolumn{6}{|l|}{ Caricetalia davallianae } \\
\hline Carex frigida & E1 & 100 & 100 & . & . \\
\hline Parnassia palustris & E1 & 47 & 43 & 50 & 20 \\
\hline Carex capillaris & E1 & 33 & 7 & . & . \\
\hline Campylium stellatum & E0 & 27 & 21 & . & . \\
\hline Carex flava s. lat. & E1 & 13 & . & . & . \\
\hline Tofieldia calyculata & E1 & 7 & 14 & . & 100 \\
\hline Carex bicolor & E1 & 7 & . & . & . \\
\hline Juncus triglumis & E1 & . & 71 & . & . \\
\hline Primula farinosa & E1 & . & 29 & . & . \\
\hline Carex davalliana & E1 & . & 21 & . & . \\
\hline Willemetia stipitata (Calycocursus stipitatus) & E1 & . & 21 & . & . \\
\hline Carex viridula & E1 & . & 21 & . & . \\
\hline Equisetum variegatum & E1 & . & 14 & . & . \\
\hline Triglochin palustre & E1 & . & 14 & . & . \\
\hline Carex panicea & E1 & . & 14 & . & . \\
\hline Eriophorum latifolium & E1 & . & 7 & . & . \\
\hline Dactylorhiza majalis & E1 & . & 7 & . & . \\
\hline Lachnea scutellata (Scutellinia scutellata) & $\mathrm{Fu}$ & . & 7 & . & . \\
\hline Blysmus compressus & E1 & . & 7 & . & . \\
\hline Eleocharis quinqueflora & E1 & . & 7 & . & . \\
\hline Kobresia simpliciuscula & E1 & . & 7 & . & . \\
\hline Molinia caerulea subsp. caerulea & E1 & . & 7 & . & . \\
\hline Luzula sudetica & E1 & & 7 & & \\
\hline Pinguicula alpina & E1 & . & . & 17 & 100 \\
\hline Carex lepidocarpa & E1 & . & . & . & 20 \\
\hline Dactylorhiza incarnata & E1 & . & . & . & 20 \\
\hline
\end{tabular}


Scheuchzerio-Caricetea fuscae

Calliergonella lindbergii

E0

Amblystegium serpens

Juncus filiformis

Carex nigra

Allium schoenoprasum subsp. alpinum

E1

Juncus articulatus

Scorpidium cossonii (Drepanocladus cossonii)

Taraxacum sect. Palustria

E0

Eriophorum scheuchzeri

E1

Aulacomnium palustre

E1

Pinguicula leptoceras

Juncus alpinoarticulatus

Eriophorum angustifolium

Juncus articulatus

Trichophorum cespitosum

Carex echinata

Scapania paludosa

Straminergon stramineum

Equisetum palustre

1

2

\section{3}

20

13

13

7

7

7
7

7

7

7

E0

E1

E1

E1

E1

E1

E1

E1

E0

E1

Cystopteridion fragilis

Cystopteris fragilis

E1

E1

Cystopteris regia

E1

Valeriana tripteris

Carex brachystachys

Orthothecium rufescens

Valeriana saxatilis

Physoplexido comosae-Saxifragion petraeae

Paederota lutea

Potentilletalia caulescenstis

Campanula cochleariifolia

E1

Valeriana elongata

Arabidetalia caeruleae (inc. Salicion herbaceae, Androsacion alpinae)

Veronica alpina

Soldanella alpina

Salix retusa

Trifolium pallescens

Carex parviflora

Taraxacum sect. Alpina

Alchemilla fissa

Saxifraga sedoides

Epilobium anagallidifolium

Galium noricum

Ranunculus traunfellneri

Sibbaldia procumbens

Doronicum glaciale

Rumex nivalis

Gentiana bavarica

Cerastion cerastioides 


\begin{tabular}{|c|c|c|c|c|c|}
\hline Successive number (Zaporedna številka) & & 1 & 2 & 3 & 4 \\
\hline Rhodiola rosea & E1 & 27 & . & 17 & . \\
\hline Cirsium spinosissimum & E1 & 27 & . & . & . \\
\hline Valeriana montana & E1 & 13 & . & . & . \\
\hline Doronicum grandiflorum & E1 & 13 & . & . & . \\
\hline Tussilago farfara & E1 & 7 & 14 & . & 80 \\
\hline Poa minor & E1 & 7 & . & . & . \\
\hline Sedum atratum & E1 & 7 & . & . & . \\
\hline Heracleum pollinianum & E1 & 7 & . & . & . \\
\hline Arabis bellidifolia & E1 & . & 14 & . & . \\
\hline Gypsophila repens & E1 & . & 7 & . & . \\
\hline Leontodon hyoseroides & E1 & . & . & 33 & . \\
\hline Cerastium carinthiacum subsp. austroalpinum & E1 & . & . & 17 & . \\
\hline Hieracium bifidum & E1 & . & . & 17 & . \\
\hline Heliosperma alpestre & E1 & . & . & . & 100 \\
\hline Petasites paradoxus & E1 & . & . & . & 60 \\
\hline Astrantia carniolica & E1 & . & . & . & 20 \\
\hline \multicolumn{6}{|l|}{ Caricion ferrugineae } \\
\hline Carex ferruginea & E1 & 33 & . & . & 20 \\
\hline Cerastium subtriflorum & E1 & 27 & . & 17 & . \\
\hline Gentiana pumila & E1 & 27 & . & . & . \\
\hline Trifolium thalii & E1 & 7 & . & . & . \\
\hline \multicolumn{6}{|l|}{ Caricetum firmae, Oxytropido-Elynion } \\
\hline Silene acaulis & E1 & 7 & . & . & . \\
\hline Minuartia verna (M. gerardii) & E1 & 7 & 7 & . & . \\
\hline Gentiana nivalis & E1 & 7 & . & . & . \\
\hline Saussurea alpina & E1 & . & 7 & . & . \\
\hline \multicolumn{6}{|l|}{ Caricion autroalpinae } \\
\hline Festuca calva & E1 & 20 & . & . & . \\
\hline \multicolumn{6}{|l|}{ Seslerietalia coeruleae } \\
\hline Galium anisophyllum & E1 & 40 & . & 17 & . \\
\hline Achillea clavenae & E1 & 27 & . & . & . \\
\hline Ranunculus carinthiacus & E1 & 13 & . & 17 & . \\
\hline Juncus monanthos & E1 & 13 & . & 17 & . \\
\hline Saussurea discolor & E1 & 7 & . & . & . \\
\hline \multicolumn{6}{|l|}{ Elyno-Seslerietea } \\
\hline Polygonum viviparum & E1 & 47 & 36 & 17 & . \\
\hline Aster bellidiastrum & E1 & 33 & 50 & 17 & 100 \\
\hline Myosotis alpestris & E1 & 27 & . & . & . \\
\hline Thymus praecox subsp. polytrichus & E1 & 20 & . & 17 & . \\
\hline Pedicularis verticillata & E1 & 20 & . & . & . \\
\hline Alchemilla vulgaris s. lat. & E1 & 20 & 14 & . & . \\
\hline Bartsia alpina & E1 & 13 & 57 & . & . \\
\hline Selaginella selaginoides & E1 & 13 & 29 & 17 & 20 \\
\hline Carex sempervirens & E1 & 13 & . & 17 & . \\
\hline Cerastium strictum & E1 & 13 & . & . & . \\
\hline Lotus alpinus & E1 & 13 & . & . & . \\
\hline Gentianella anisodonta & E1 & 13 & . & . & . \\
\hline Astrantia bavarica & E1 & 13 & . & . & . \\
\hline Agrostis alpina & E1 & 13 & . & . & . \\
\hline Sesleria caerulea & E1 & 7 & 21 & . & . \\
\hline Rhinanthus glacialis & E1 & 7 & 7 & . & . \\
\hline Phyteuma orbiculare & E1 & 7 & . & . & . \\
\hline Scabiosa lucida subsp. lucida & E1 & 7 & . & . & . \\
\hline
\end{tabular}




\begin{tabular}{ll}
\hline Successive number (Zaporedna številka) & \\
\hline Polygala alpestris & $\mathrm{E} 1$ \\
Homogyne discolor & $\mathrm{E} 1$ \\
Ligusticum mutellina & $\mathrm{E} 1$ \\
Ranunculus montanus & $\mathrm{E} 1$ \\
Mulgedio-Aconitetea & \\
Viola biflora & $\mathrm{E} 1$ \\
Aconitum lycoctonum subsp. ranunculifolium & $\mathrm{E} 1$ \\
Peucedanum ostruthium & $\mathrm{E} 1$ \\
Chaerophyllum hirsutum & $\mathrm{E} 1$ \\
Veratrum album & $\mathrm{E} 1$ \\
Thalictrum aquilegiifolium & $\mathrm{E} 1$ \\
Hypericum maculatum & $\mathrm{E} 1$ \\
Alchemilla xanthochlora & $\mathrm{E} 1$ \\
Epilobium alpestre & $\mathrm{E} 1$ \\
Lamium maculatum & $\mathrm{E} 1$ \\
Pedicularis recutita & $\mathrm{E} 1$ \\
Juncetea trifidi, Nardion strictae &
\end{tabular}

Juncetea trifidi, Nardion strictae

Festuca nigrescens

Juncus jacquinii

Euphrasia minima (inc. E. pulchella)

Campanula scheuchzeri

Anthoxanthum nipponicum

Scorzoneroides helvetica

Potentilla erecta

Primula integrifolia

1
7
7
.
.

\section{2} 29

Poo alpinae-Trisetetalia

Poa alpina

Crepis aurea

Trifolium badium

Euphrasia picta

$\begin{array}{ll}53 & 21 \\ 33 & . \\ 27 & . \\ 20 & . \\ 20 & . \\ 13 & . \\ 13 & . \\ 7 & . \\ 7 & . \\ 7 & 7 \\ . & .\end{array}$

21

33

Trollius europaeus

Calthion

Crepis paludosa

Caltha palustris

Ranunculus aconitifolius

E1

E1

E1

E1

E1

Molinio-Arrhenatheretea

Deschampsia cespitosa

Leontodon hispidus

Dactylis glomerata

Festuca arundinacea

Trifolium repens

Trifolium pratense

Agrostis stolonifera

Leontodon autumnalis

Festuco-Brometea

Cirsium erisithales

E1

Buphthalmum salicifolium

Koeleria pyramidata

Carlina acaulis

Helictotrichon praeustum

Briza media

Cirsium acaule

Gymnadenia conopsea 


\section{Betulo-Alnetea}

Salix waldsteiniana

Vaccinio-Piceeta

Calamagrostis arundinacea

Fagetalia sylvaticae

Daphne mezereum

Querco-Fagetea

Carex flacca

Alnion incanae, Salicetea purpureae

Alnus incana

Salix eleagnos

Other species (Ostale vrste)

Agrostis sp.

Sagina sp.

\section{Mosses (Mahovi)}

Brachythecium rutabulum

Plagiochila porelloides

Ptilidium ciliare

Plagiomnium rostratum

Hylocomium splendens

Lescuraea incurvata

Rhytidium rugosum

Barbilophozia attenuata

Barbilophozia hatcheri

Climacium dendroides

Hypnum vaucheri

Tortella densa

Timmia norvegica

Sciuro-hypnum curtum (Brachythecium curtum)

Drepanocladus sp.

Alectoria subulata

Blinda acuta

Bryum torquescens

Dicranella squarrosa

Pohlia wahlenbergii (Mniobryum albicans)

Mnium sp.

Meesia trichodes

Sphagnum subsecundum

Bryum sp.

Meesia uliginosa

Hygroamblystegium tenax (Amblystegium tenax)

Eurhynchium angustirete

Isothecium alopecuroides

Brachythecium sp.
E1

27

E1

E1

E1

14

40

E2

E2

E1

E1

E0

E0

E0

E0

E0

E0

E0

E0

E0

E0

E0

E0

E0

E0

E0

E0

E0

E0

E0

E0

E0

E0

E0

E0

E0

E0

E0

E0

E0

13

. 20

20

7

7

47

20

7

7

7

7

7

7

7

7

7

7

7

7
7

. 21

7

7

. 7

. 7

. 7

. 7

. 7

. 7

. 14

\section{Legend - Legenda}

1 Palustriello decipientis-Caricetum frigidae

2 Saxifrago aizoidis-Caricetum frigidae

3 Cratoneuretum falcati

4 Cratoneuretum commutati
ID Igor Dakskobler

AM Andrej Martinčič

$\mathrm{BrBl}$ Josias Braun-Blanquet

BS Boštjan Surina

EA Ervin Aichinger 


\begin{tabular}{|c|c|c|c|c|c|c|c|c|c|c|c|c|c|c|c|}
\hline 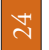 & 0ててゅゥて & WVZgđI & $0 \angle 9 \mathrm{I}$ & 됭 & $\approx$ & IJ & I & $\stackrel{0}{2}$ & $R$ & 우 & $\stackrel{\sim}{\sim}$ & ㄱ & & ZI0Z/IE/L & 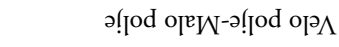 \\
\hline$\approx$ & $\mathrm{I} z Z \angle \angle Z$ & WVGSAI & 0002 & 多 & $\curvearrowleft$ & ЧวТ & ! & 8 & $\approx$ & 으 & 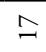 & 으 & & $6 \mathrm{I} 0 \mathrm{Z} / \angle \mathrm{I} / L$ & 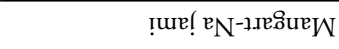 \\
\hline ป & $\angle \angle 89 \angle 2$ & WVAI & $0 \mp 6 \mathrm{I}$ & $\infty$ & 尺 & $\mathrm{T}$ & ! & 8 & i̊ & $\stackrel{0}{-}$ & $\approx$ & 으 & & $6 \mathrm{~L} 0 \mathrm{z} / 8 \mathrm{z} / 8$ & 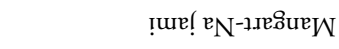 \\
\hline $\bar{\tau}$ & $\$ 696 \varsigma 2$ & WVMIL & $026 \mathrm{I}$ & is & 은 & ID & ! & 아 & 8 & i & $\approx$ & 으 & & $\varepsilon 86 \mathrm{~L} / 9 / 8$ & 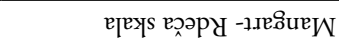 \\
\hline 요 & $8 Z S \angle I Z$ & WHZgCI & ऽ86I & o & o & $\mathrm{T}$ & !1 & 요 & $\stackrel{\circ}{1}$ & $\stackrel{\circ}{1}$ & $\cong$ & 음 & & $\angle 00 Z / 9 Z / L$ & 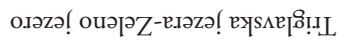 \\
\hline$\approx$ & $\varepsilon 9 \tau \angle L \tau$ & WVGSAI & $0 \angle 6 \mathrm{I}$ & 0 & o & $\mathrm{T}$ & ! & $\because$ & $\curvearrowleft$ & $\because$ & $\hat{n}$ & $\psi$ & & 6I0Z/EZ/L & 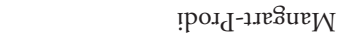 \\
\hline$\infty$ & $\tau \varepsilon \varepsilon 9 \angle \tau$ & WHgSZgđI & $0 z 0 z$ & $\infty$ & - & WT & Ю & $n$ & 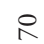 & ஓ & $\overleftrightarrow{\sim}$ & 요 & & 6L0Z/L/8 & 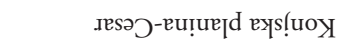 \\
\hline$\approx$ & $\angle 09 \angle \mathrm{IZ}$ & 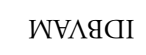 & ऽ69I & 学 & $n$ & $\mathrm{~T}$ & ! & 0 & 8 & 구 & $\hat{\imath}$ & $ㅇ$ & & $\angle 00 Z / \mathcal{E} \mathrm{I} / L$ & 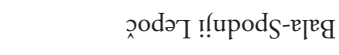 \\
\hline$\because$ & $909 \angle \mathrm{I} Z$ & 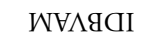 & 069 I & 之 & n & $\mathrm{T}$ & ! & 0 & 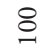 & ำ & $\widehat{\imath}$ & $\circ$ & & $\angle 00 Z / \mathcal{E} \mathrm{I} / L$ & ग्रodəา !!fupods-ereg \\
\hline$\simeq$ & $66 S \angle I Z$ & WHAgđI & $0 Z \angle \mathrm{I}$ & 䒺 & ¿ & $\mathrm{T}$ & $! 7$ & 구 & $\triangleright$ & 구 & $\vec{m}$ & N & & $\angle 00 Z / \mathcal{E} \mathrm{I} / L$ & 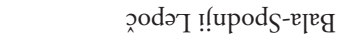 \\
\hline$\varpi$ & $\varsigma \angle 89 \angle Z$ & WVAI & $0 Ð 6 \mathrm{I}$ & 多 & in & WT & IO & 오 & 요 & in & $\hat{n}$ & $ㅇ$ & & $6 \mathrm{I} 0 \mathrm{z} / 8 \mathrm{z} / 8$ & 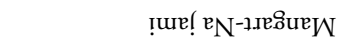 \\
\hline 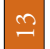 & SI $89 \angle Z$ & WVAI & $0 \varsigma 6 \mathrm{I}$ & 댕 & 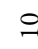 & WT & ID & $n$ & $R$ & in & থे & $N$ & & $6[0 z / 8 z / 8$ & !ure! $\mathrm{e}_{\mathrm{N}-1.1 .88 \mathrm{x}} \mathrm{W}$ \\
\hline$\approx$ & 6でリカて & WVAI & 0I6I & 땡 & $\circ$ & $\mathrm{T}$ & ! & in & $R$ & in & ㄱ. & $\sim$ & & $Z \mathrm{I} 0 \mathrm{Z} / \angle \mathrm{I} / 8$ & ч!̣ure \\
\hline$=$ & $6 \mathcal{E L I Z 8 Z}$ & WVAI & 088 I & is & $n$ & $\mathrm{~T}$ & ! & 아 & 8 & ㄱ & $\approx$ & in & & $0 z 0 Z / \angle Z / L$ & !uәрәчS !ysueqeg !!e \\
\hline$ㅇ$ & $0 z z \angle L z$ & WVgSAI & $000 z$ & 8 & $\infty$ & ЧวТ & ! & ำ & $\infty$ & 8 & $\tilde{n}$ & 으 & & $6 \mathrm{I} 0 \mathrm{Z} / \mathrm{LI} / \mathrm{L}$ & 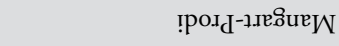 \\
\hline a & 6ZऽEIZ & WVGSAI & $0 \varsigma 0 Z$ & 8 & ণ & ЧวТ & ! & 으 & $\infty$ & 우 & $\vec{\sim}$ & & & $\varsigma 00 Z / 8 Z / L$ & !po. $_{d}-1$. Iesur $W$ \\
\hline$\infty$ & 6IIJIZ & WVCI & $0 \angle \angle \mathrm{I}$ & s & 요 & WT & I & 으 & 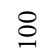 & 우 & 가 & v & & $\mp 00 z / 8 / 6$ & 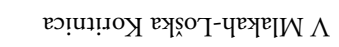 \\
\hline$\wedge$ & ZZ9LIZ & WVAI & $08 \angle \mathrm{I}$ & 㞬 & 요 & $\mathrm{T}$ & !] & 음 & ฉ & 고 & ก & $\stackrel{-}{2}$ & & $\angle 00 Z / Z \mathrm{I} / L$ & 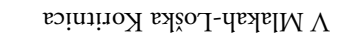 \\
\hline 6 & z8970Z & WVAI & 00Ð I & n & ণ & ЧวІО & oว & $n$ & 8 & iి & †े & $n$ & $\varepsilon 007^{\circ}$ II pue & $z 00 z \cdot \angle \cdot \mathcal{E}$ & 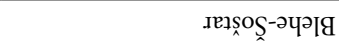 \\
\hline$n$ & $\varepsilon 8970 z$ & WVAI & $06 \varepsilon \mathrm{I}$ & 贸 & in & ЧวІつ & оว & ○ & 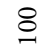 & $n$ & $\underset{\forall}{*}$ & $\sim$ & $\varepsilon 007^{\circ}$ I I pue $^{2}$ & $\tau 00 z \cdot L \cdot \varepsilon z$ & 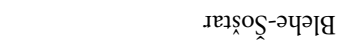 \\
\hline$\psi$ & I8920Z & WVAI & $88 \mathcal{E} \mathrm{I}$ & s & in & Чวાગ & оว & o & 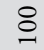 & $\cong$ & $n$ & $\psi$ & $\varepsilon 007^{\circ}$ I I pue $^{\circ}$ & $z 00 z \cdot \angle \cdot \varepsilon z$ & 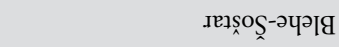 \\
\hline$m$ & $\mp 89202$ & WVAI & $0 \angle \mathcal{E} \mathrm{I}$ & 学 & \& & Чวอ & oว & $n$ & 8 & 으 & 아 & N & $\varepsilon 007^{\circ}$ I I pue & $z 00 z \cdot \angle \cdot \mathcal{E} Z$ & 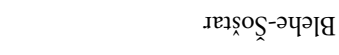 \\
\hline v & $08920 z$ & WHAI & $08 \mathcal{E} \mathrm{I}$ & 8 & 尺ิ & ЧวІว & оว & $n$ & 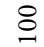 & $\because$ & $\bar{m}$ & - & $\varepsilon 007^{\circ}$ i I pue & $z 00 z \cdot L \cdot \varepsilon z$ & 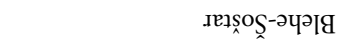 \\
\hline- & $\varsigma 8970 Z$ & WVCI & $0 \angle \varepsilon \mathrm{I}$ & Z & in & ЧวІว & oว & ㄱ & $\infty$ & 고 & 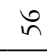 & 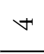 & $\varepsilon 007^{\circ} 9^{\circ}$ I pue & $z 00 z \cdot L \cdot \varepsilon \tau$ & 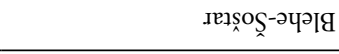 \\
\hline 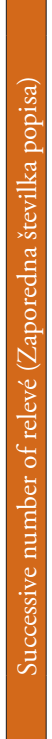 & 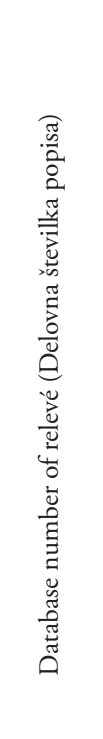 & 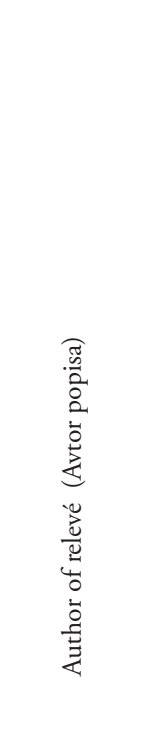 & 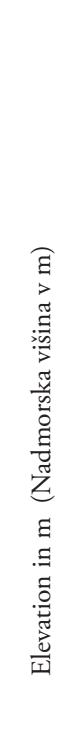 & 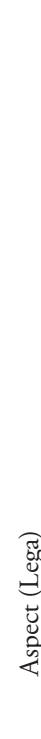 & 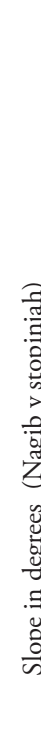 & 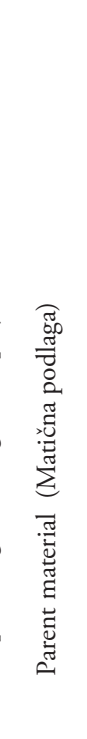 & $\begin{array}{l}\frac{\overparen{O}}{E} \\
\overrightarrow{\bar{D}} \\
\text { D }\end{array}$ & 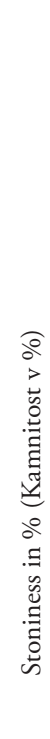 & 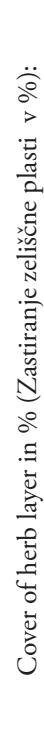 & 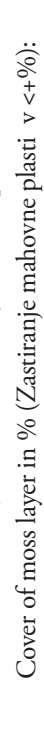 & 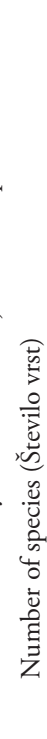 & 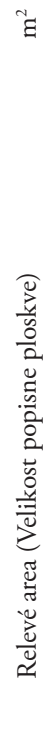 & 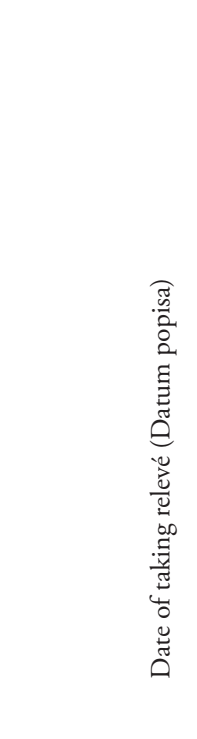 & & 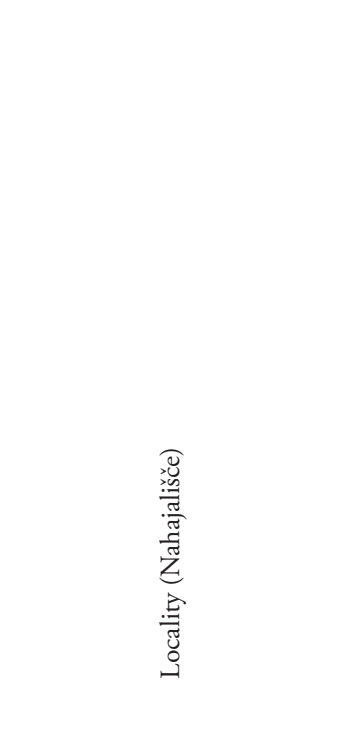 \\
\hline
\end{tabular}




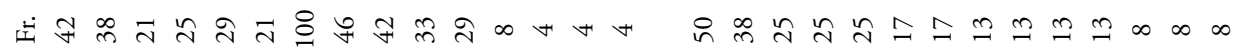

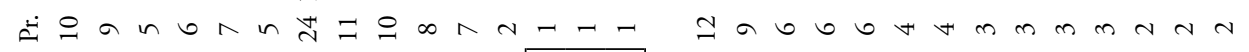

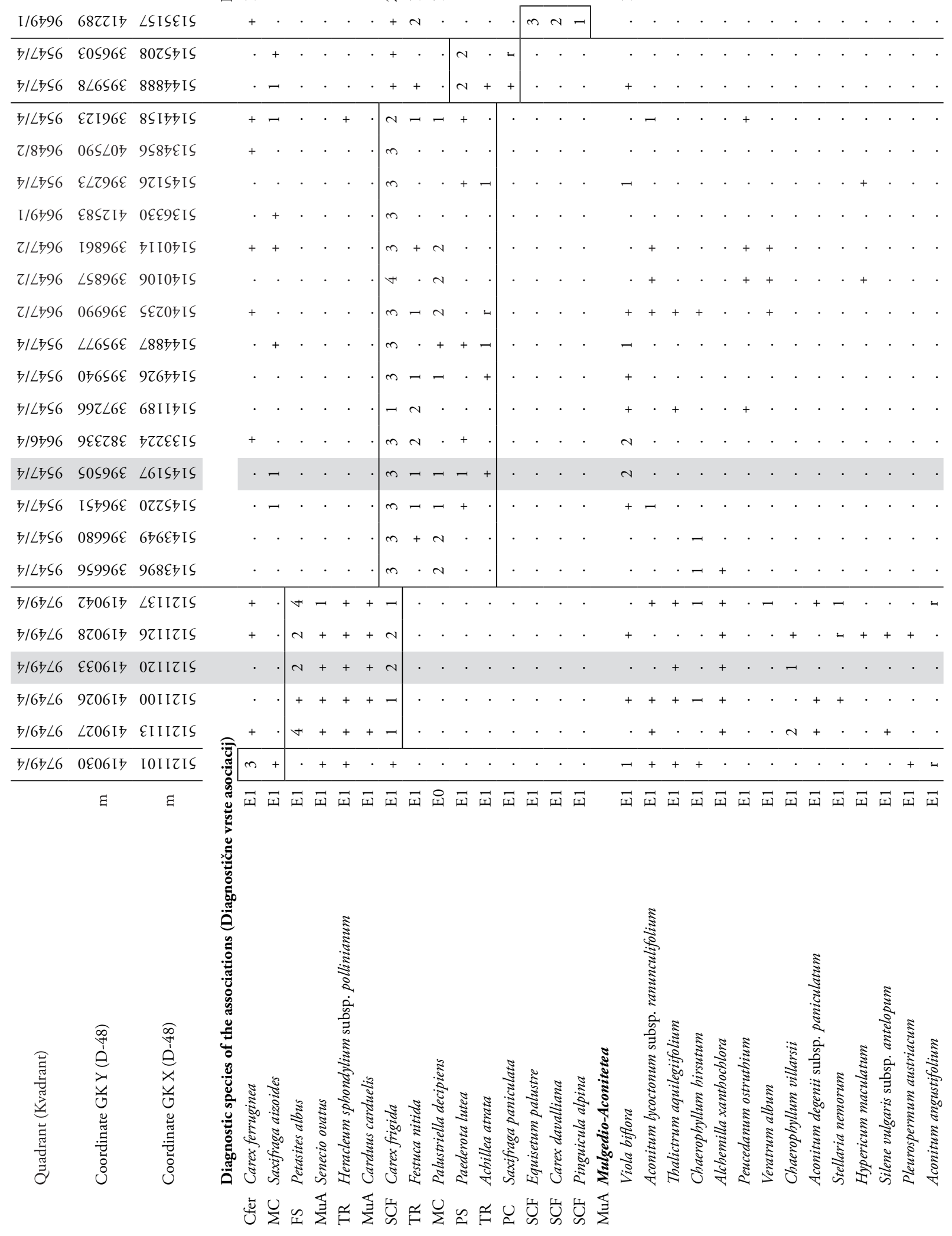




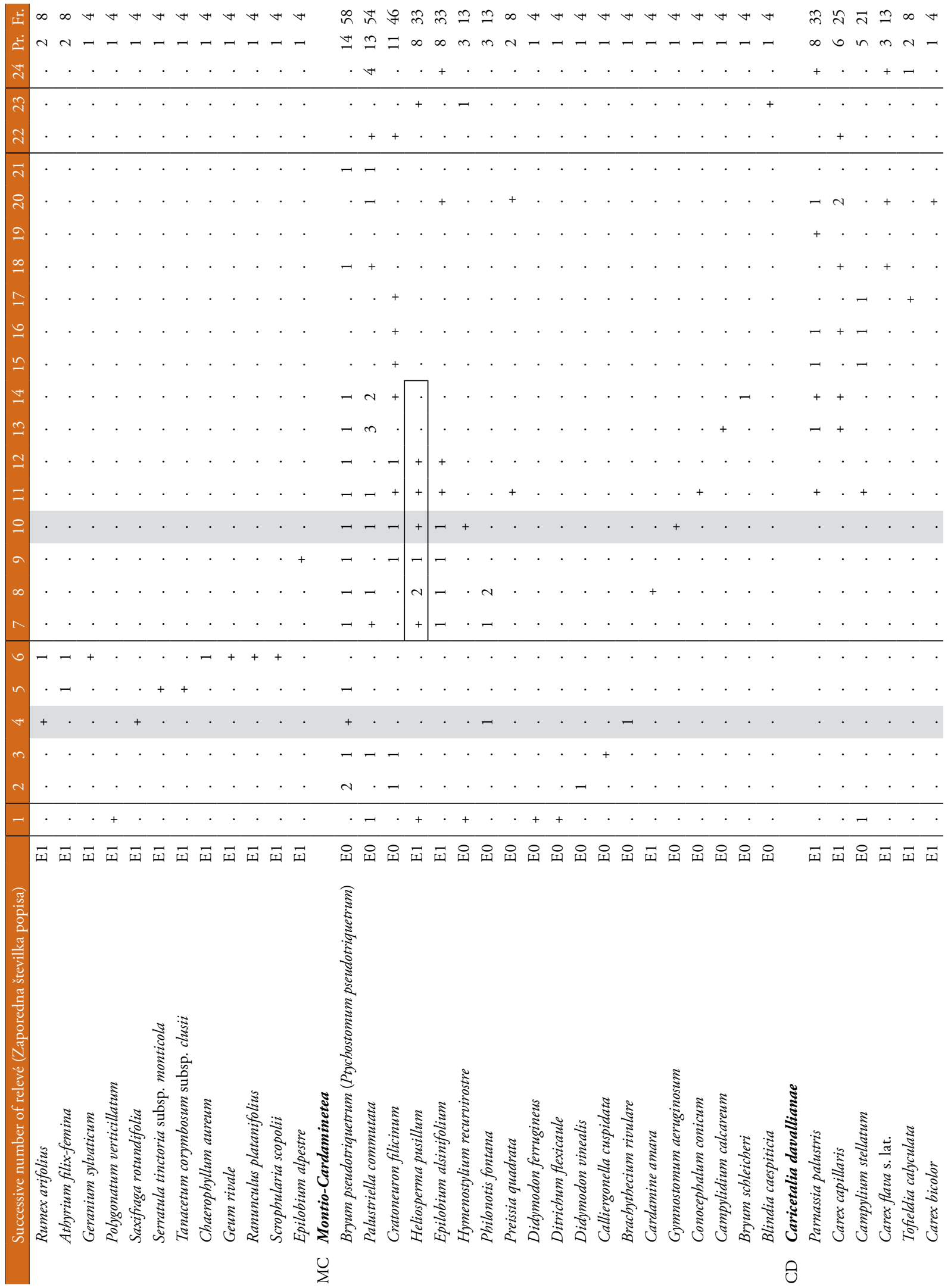




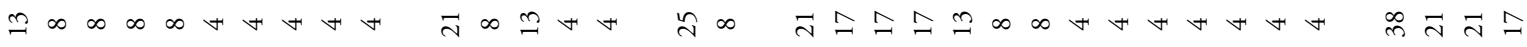

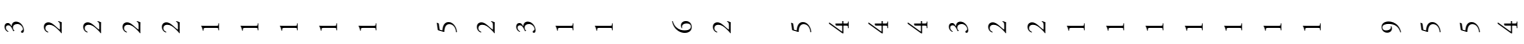
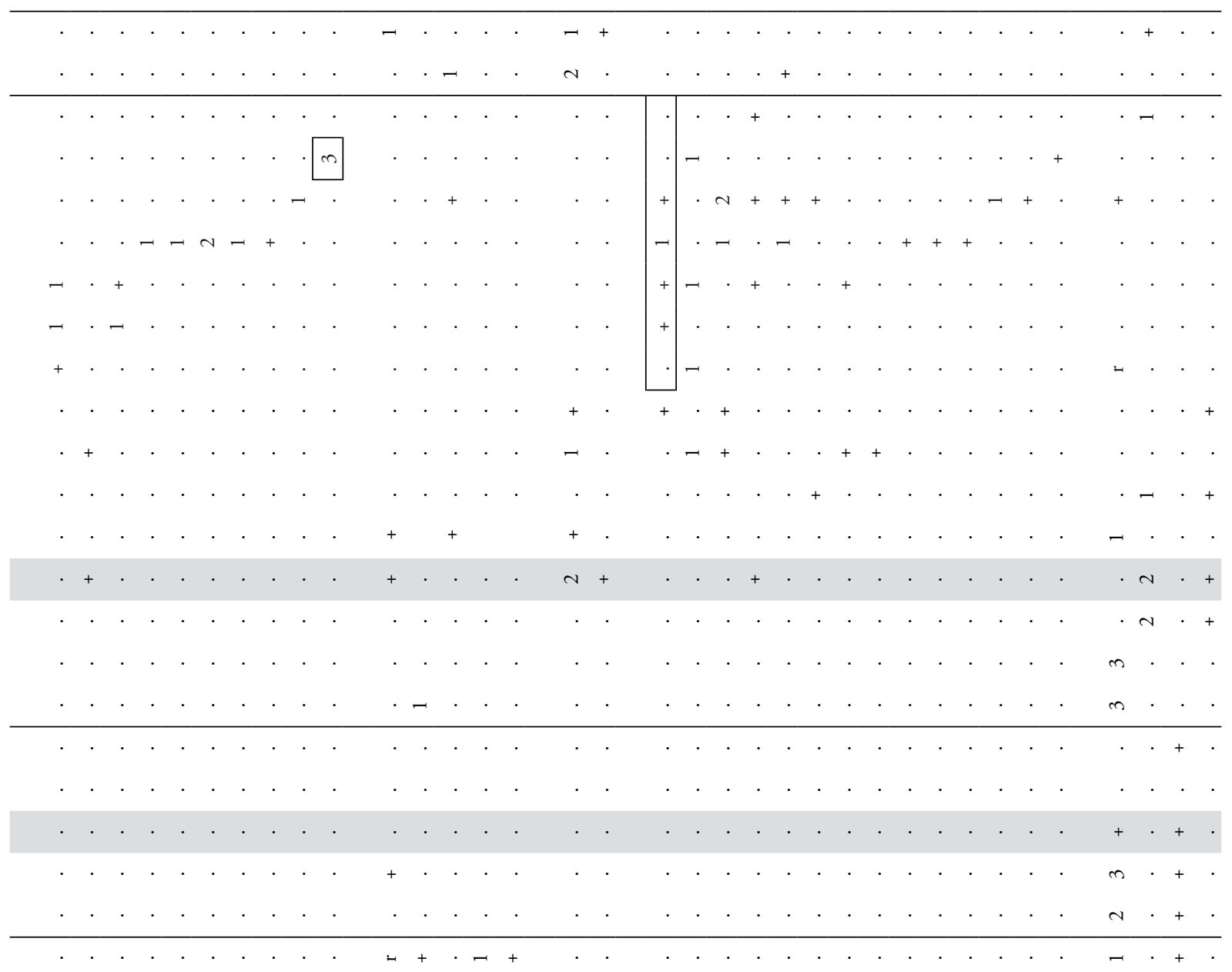

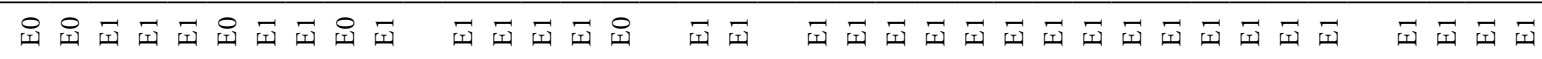

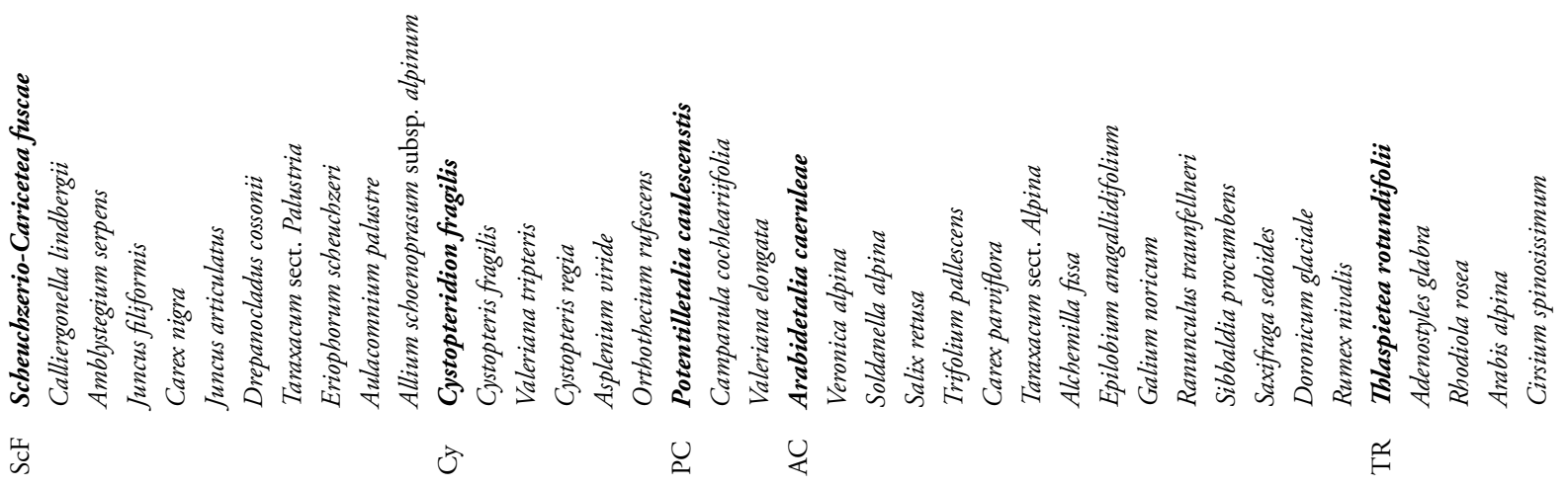




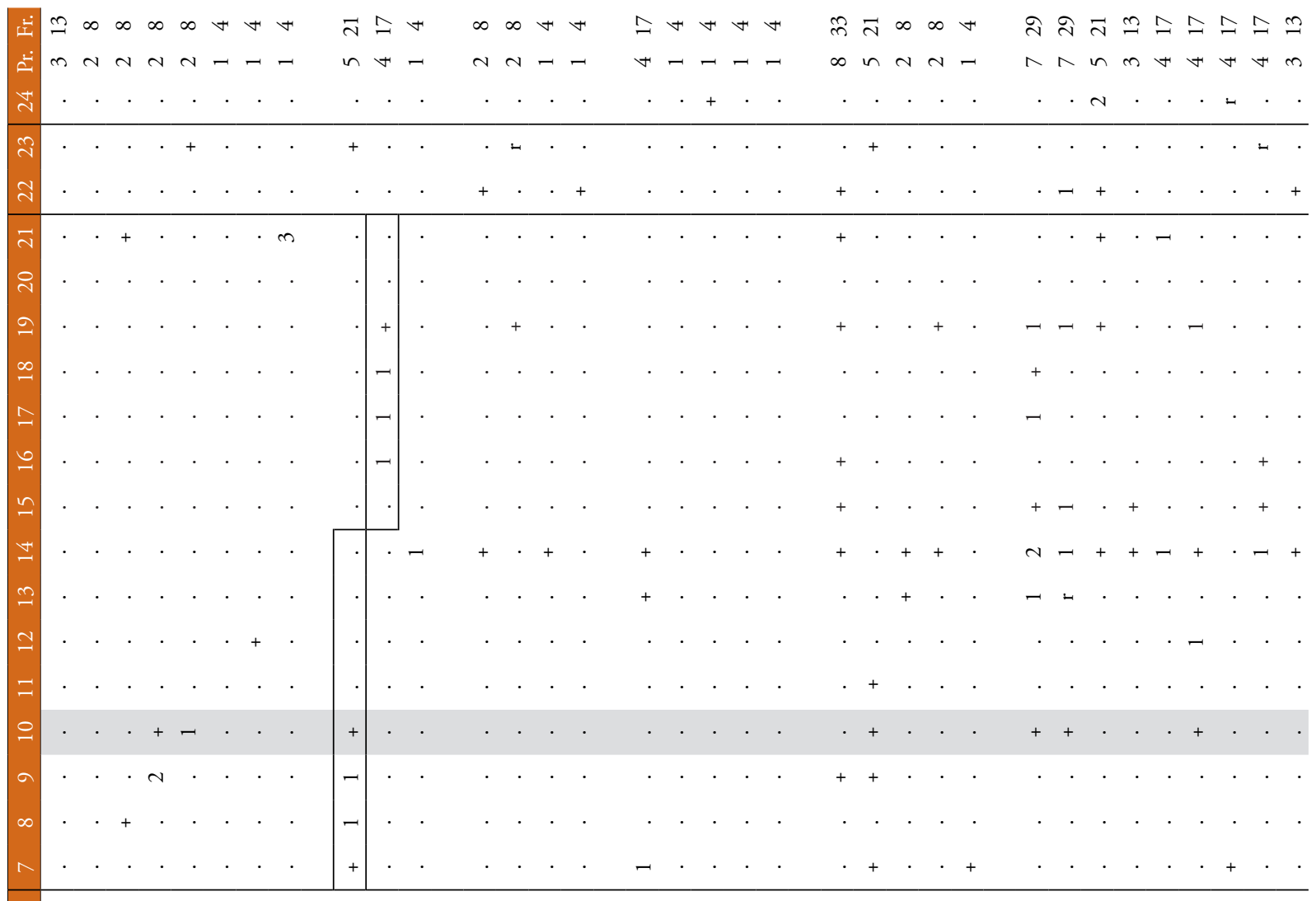

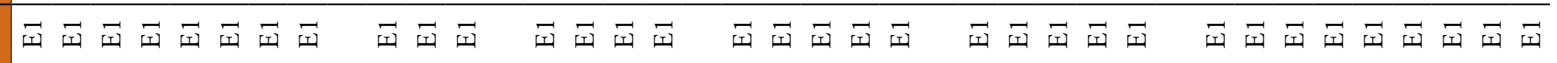

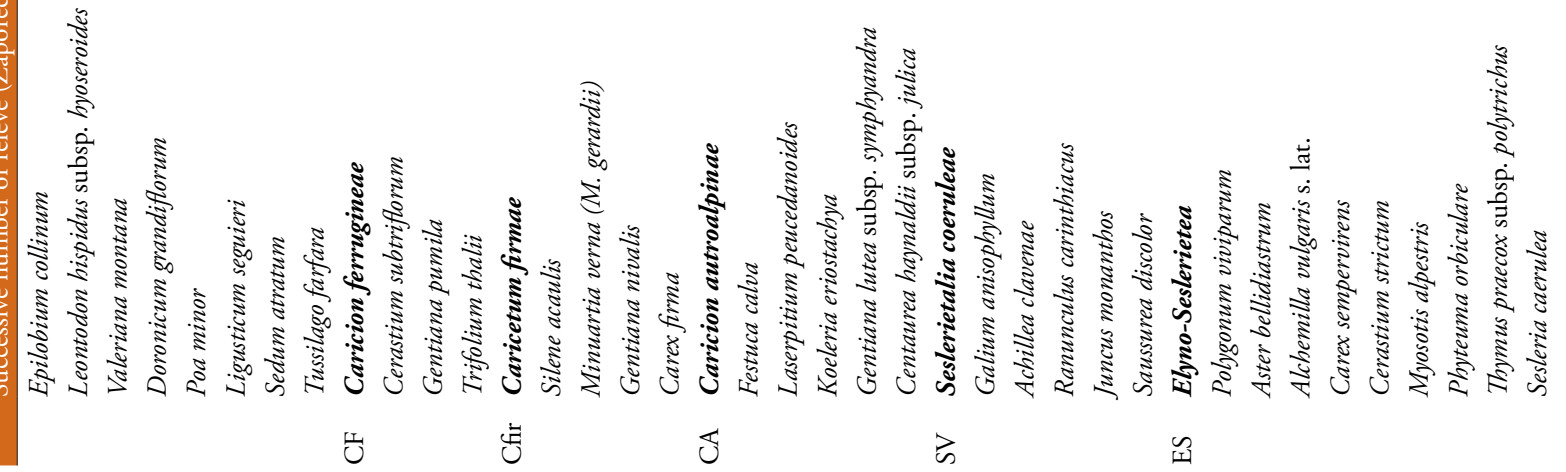




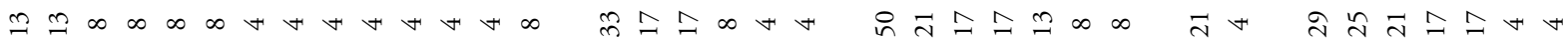

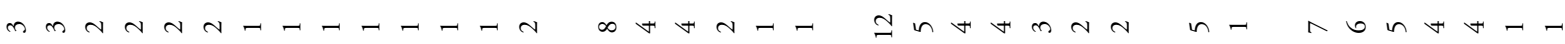

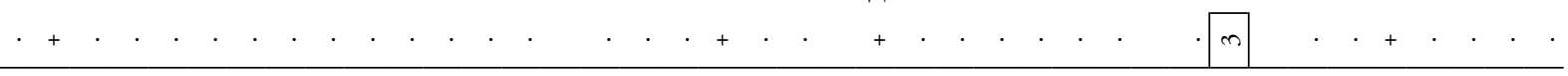
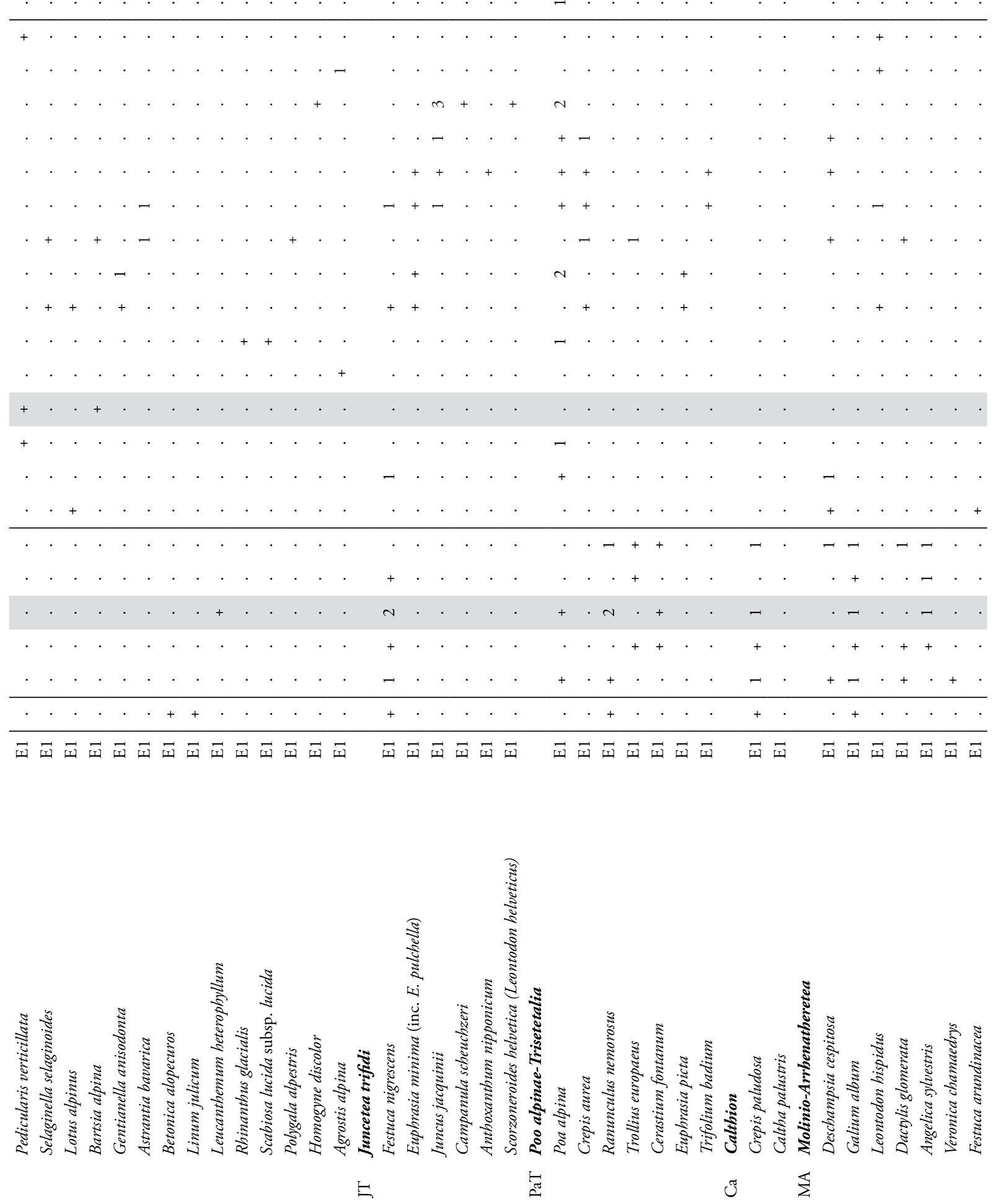


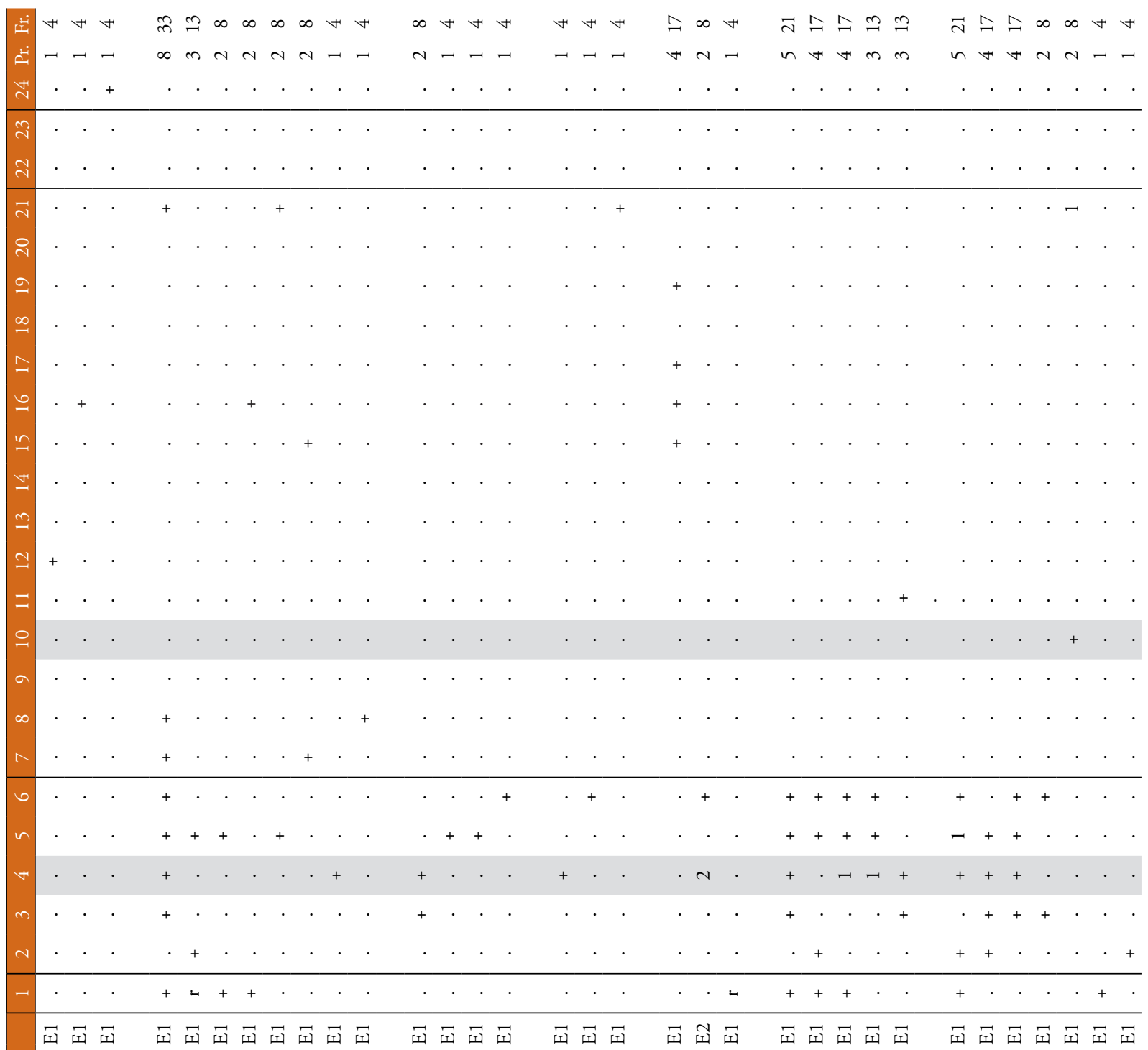




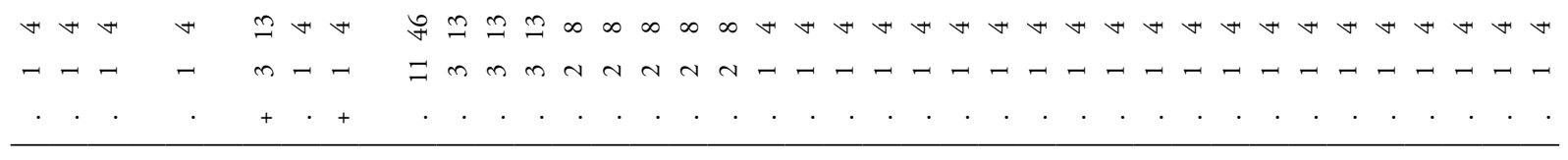

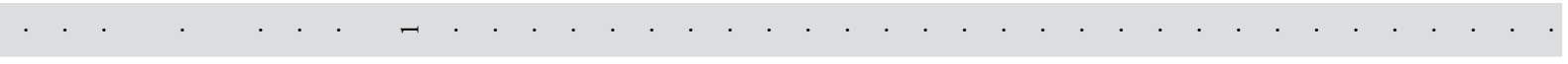

\begin{tabular}{|c|c|c|c|c|c|c|c|c|c|c|c|c|c|c|c|c|c|c|c|c|c|c|c|c|c|c|c|c|c|c|c|c|c|}
\hline+ & + & + & . & . & . & . & . & . & . & . & . & . & . & . & . . & . . & . & $\cdot$ & . & . & . & & . & . & & & & . . & . & & $N$ & & \\
\hline$\cdot$ & . & . & + & . & . & $\cdot$ & - & + & + & . & . & + & . & . & . . & . . & . & . & . & . & . & . & . & . & . & & & $\cdot-$ & + & + & . & . & \\
\hline . & . & . & . & . & . & . & & + & + & + & + & + & + & + & . . & . & . & . & . & . & & - & + & & & & $+\quad+$ & + & . & . & . & . & \\
\hline$\cdot$ & . & . & . & . & . & . & - & . & . & . & . & . & . & . & . . & . . & . & . & . & . & + & . & . & . & & . & . & . & . & . & . & . & \\
\hline$\cdot$ & . & . & . & $\cdot$ & . & . & + & . & . & . & . & . & . & . & . . & . . & . & . & . & . & . & . & . & . & & . & & . . & . & . & . & . & \\
\hline 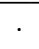 & . & . & . & $\cdot$ & $\cdot$ & . & + & - & + & & + & . & . & . & . - & + & + & + & + & + & . & $\cdot$ & . & . & & . & & . . & . & . & . & . & \\
\hline
\end{tabular}

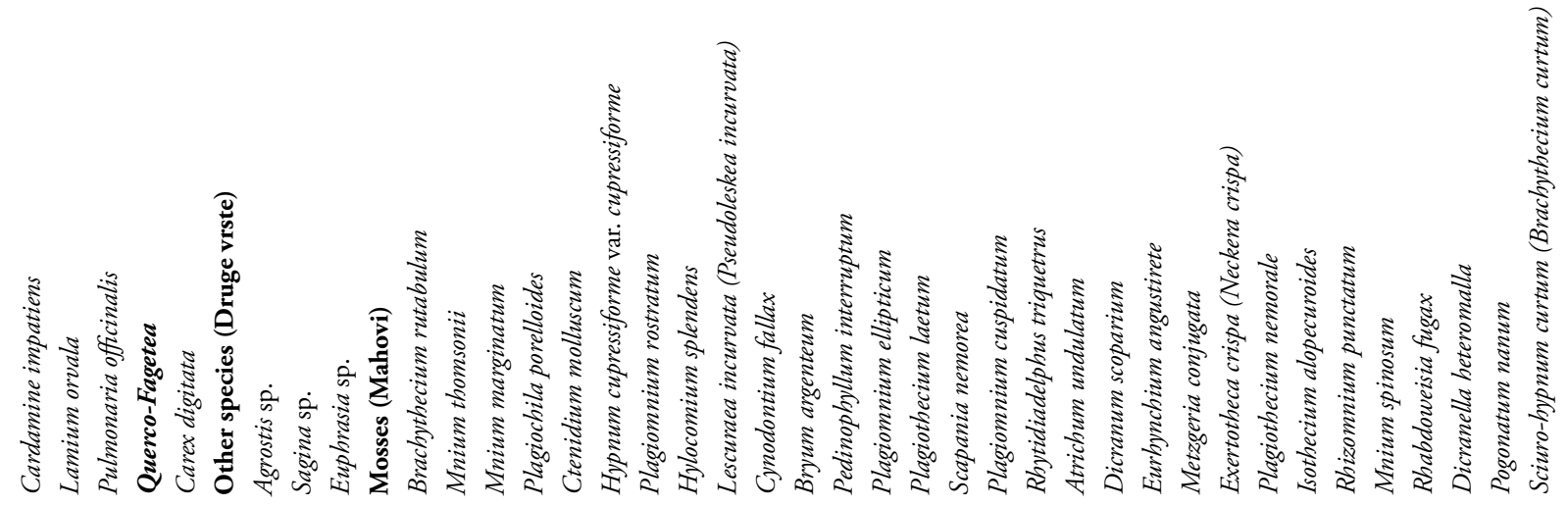
岁 0 इ 

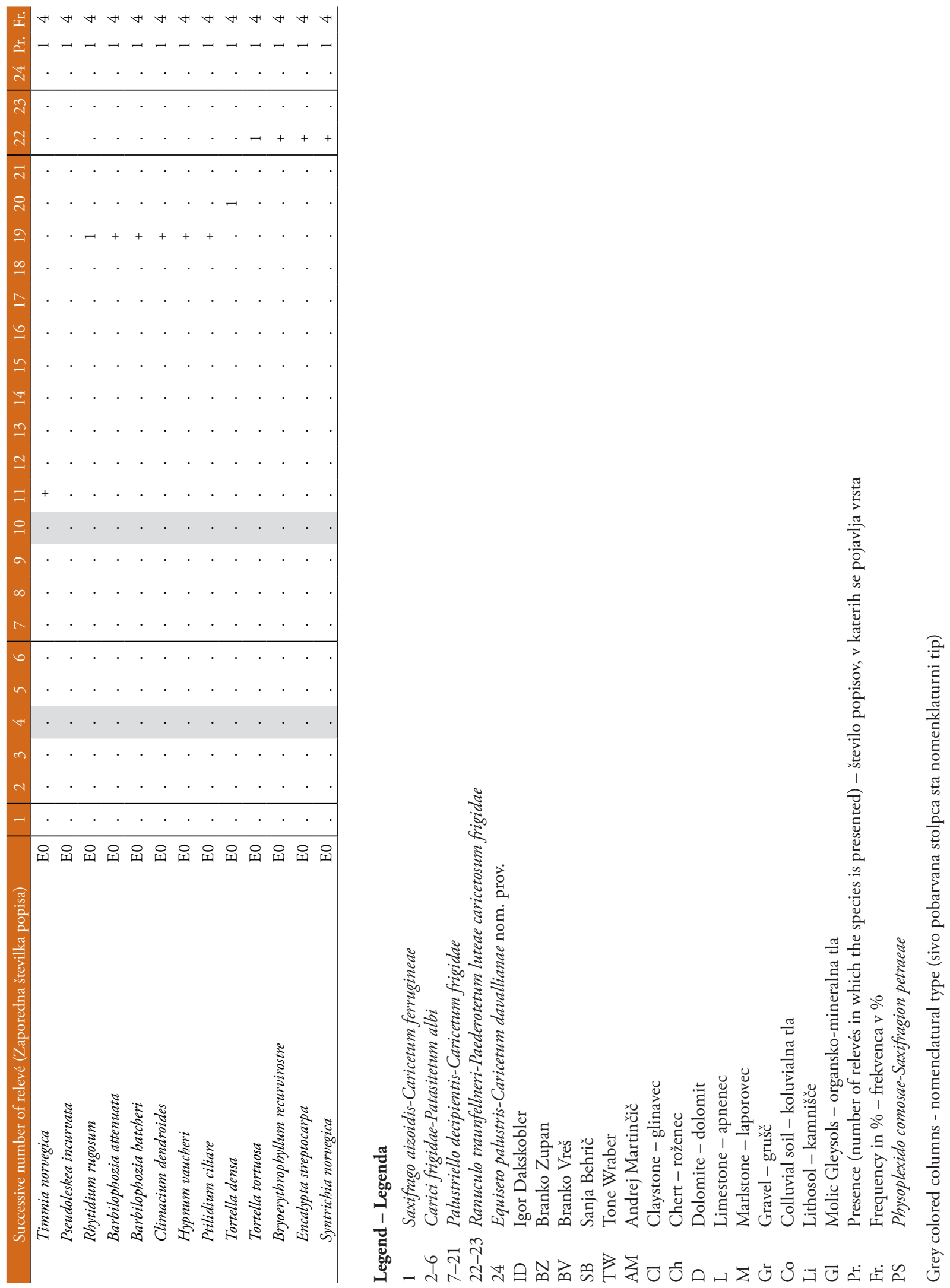